Buca Eğitim Fakültesi Dergisi, 2021, say1 52, s. 439-464

Araştırma Makalesi
The Journal of Buca Faculty of

Education, 2021, issue 52, p. 439-464

Research Article

\title{
Okul Öncesi Kaynaştırma Sınıfındaki Otizmli Bir Çocuğun Akran İlişkilerinin İncelenmesi*
}

\section{Investigation of the Children's Peer Relationships in the Inclusive Preschool Classroom of a Child with Autism}

\author{
Hazel Sila MENTEŞ ${ }^{1}$, Yaşare AKTAŞ ARNAS ${ }^{2}$ \\ ${ }^{1}$ Sorumlu Yazar, Doktora Öğrencisi, Okul Öncesi Ĕ̆itimi, Ĕ̆itim Bilimleri Enstitüsü, Hacettepe \\ Üniversitesi, Türkiye, silamentes@hacettepe.edu.tr, (https://orcid.org/0000-0003-4524-4335) \\ ${ }^{2}$ Prof. Dr., Okul Öncesi Öğretmenliği, Eğitim Fakültesi, Hasan Kalyoncu Üniversitesi, Türkiye, \\ yasare.aktas@hku.edu.tr, (https://orcid.org/0000-0002-0738-9325)
}

Geliş Tarihi: 24.04 .2021

Kabul Tarihi: 14.12.2021

\section{ÖZ}

Bu çalışmanın amacı, okul öncesi kaynaştırma sınıfındaki otizmli bir çocuğun akran ilişkilerinin incelenmesidir. Akran ilişkileri kapsamında, sınıf içerisindeki akran kabul, ret ve zorbalık davranışları, normal gelişim gösteren çocukların otizmli çocuğa ilişkin tanımları ve otizmli çocuğun sınıf içerisindeki sosyal konumu incelenmiştir. Araştırmaya, bir okul öncesi kurumundaki kaynaştırma sınıfına devam eden, 1 otizmli çocuk ve 21 normal gelişim gösteren çocuk katılmıştır. Nitel yaklaşımlardan durum araştırması olarak gerçekleştirilen bu araştırmada veri toplama yöntemi olarak görüşme (sosyometri, çiz-anlat uygulaması) ve gözlem kullanılmıştır. Verilere içerik analizi uygulanmıştır. Araştırma sonucunda, otizmli çocuğun akran kabulü davranışlarının yanında akran reddi ve zorbalığı davranışları da görülmüştür. Sözel şiddet, otizmli çocukta dönem başında gözlenmezken, normal gelişim gösteren çocuklar tarafından ilk aydan itibaren uygulanmıştır. Normal gelişim gösteren çocukların, süreç içerisinde prososyal davranışlar geliştirdiği saptanmıştır. Normal gelişim gösteren çocukların otizmli çocuğu kendilerinden yaşça küçük olduğunu düşündükleri ortaya çıkmıştır. Otizmli çocuğun, dışlanan-ihmal edilen çocuk kategorisinde yer aldığı saptanmıştır. Sonuçlar, kaynaştırma sınıfındaki çocuklar arasında uygun etkileşim kurulamadığında sosyal deneyimlerin olumsuz yöne doğru ilerlediğini göstermiş ve ilgili alanyazın ile tartışılmıştır.

Anahtar sözcükler: Akran ilişkileri, akran kabulü, akran reddi, okul öncesi kaynaştırma, otizm spektrum bozukluğu.

\begin{abstract}
The purpose of this study was to investigate the peer relationships of a child with autism in a preschool inclusive classroom. Within the scope of peer relationships, peer acceptance, rejection and bullying behaviors in the classroom, the definitions of the children with normal development of the child with autism and the social position of the child with autism in the classroom were examined. One child with autism and 21 normally developing children attending an inclusive class in a pre-school institution, participated in the study. Interview (sociometry, draw-tell application) and observation were used as data collection methods in this study, which was carried out as a case study, one of the qualitative approaches. Content analysis was applied to the data. As a result of the study, although the peer acceptance behaviors of the autistic child were quite intense, peer rejection and bullying behaviors were also observed to be intense. While verbal violence was not observed in the child with autism at the beginning of the term, it was used by the children
\end{abstract}

\footnotetext{
* Bu makale tez çalışmasından üretilmiştir. Çalışma için: Menteş, H. S. (2020). Otizm spektrum bozukluğuna sahip bir çocuğun okul öncesi kaynaştırma sınıfındaki akran ilişkilerinin incelenmesi (Yayınlanmamış Yüksek Lisans Tezi). Çukurova Üniversitesi Sosyal Bilimler Enstitüsü, Adana.
} 
with normal development from the first month. It has been found that children with normal development develop prosocial behaviors in the process. It has been revealed that normally developing children think the child with autism is younger than them. It has been determined that the child with autism is in the excluded-neglected child category. The results were discussed with the literature and that social experiences tended to progress when appropriate interaction could not be established among children in inclusive classrooms.

Keywords: Peer relations, peer acceptance, peer rejection, preschool inclusion, autism spectrum disorder.

\section{GíRIŞ}

Okul öncesi eğitim kurumları, genellikle özel gereksinimli çocukların akranlarıyla etkileşim kurma ve deneyim kurma firsatı edindikleri ilk ortamlardır (Wood, Cowan ve Baker, 2002). Bu çocukların, çevreye uyum sağlaması, gelişim açısından akranlarına yetişmesi ve sosyal becerilerinin geliştirilmesi kaynaştırma programları ile sağlanabilmektedir (Odom, Deciyan ve Jenkins, 1984). Okul öncesi kurumlarındaki kaynaştırma sınıfları bu açıdan çok önemli olmakla beraber; verim elde edilebilmesi için, çocukların birbirlerine karşı tutumları ve akran ilişkileri kritik önem taşımaktadır (Güzel ve Özmen, 2003).

Akran ilişkileri, genel olarak aynı yaşta veya gelişim düzeyinde olan bireyler arasındaki etkileşim bütünü şeklinde tanımlanmaktadır (Beyazkürk, Anliak ve Dinçer, 2007). Genellikle arkadaşlık ile karıştırılan bu kavram, olumlu ve olumsuz etkileşimleri (şiddet, dışlama, reddetme) beraber içermesi yönüyle arkadaşlıktan farklılaşmaktadır (Ogelman ve Aytaç, 2020). $\mathrm{Bu}$ ilişkiler; akran kabulü, akran reddi ve akran zorbalığı olmak üzere üç boyutta incelenebilmektedir (Hartup, 1970). Hartup'a göre akranlarınca kabul gören çocukların, sosyal becerileri yeterli, işbirlikçi, insancıl ve başarılı oldukları, akranları tarafından sevilip tercih edildikleri bilinmektedir. Çocuğun aynı yaştaki arkadaşları tarafından tercih edilmemesi, sevilmemesi ve olumsuz algılanması ise akran reddine dair belirtilerdir. Fiziksel, sözel ve dolaylı şiddeti içeren, psikolojik problemlere yol açan ilişki türü ise akran zorbalığ 1 olarak tanımlanmaktadır (Crick, 1995).

Akran ilişkilerine yön veren önemli unsurlardan biri, çocuğun sınıf içerisindeki sosyal konumudur. Sosyal konum, çocukların akranları tarafından ne kadar sevildiği veya sevilmediği ifade etmek için kullanılan, sosyal etki ve tercihlerle ortaya çıkan bir kavram olarak tanımlanmaktadır. Çocukların sosyal konumu; popüler, reddedilen, tartışmalı, dışlanan ve ortalama olmak üzere beş gruba ayrılmaktadır. İlgili alanyazında, okul öncesi kaynaştırma sınıflarındaki, özel gereksinimli ve normal gelişim gösteren çocukların birbirlerine karşı pozitif tutumlar sergiledikleri, sosyal etkileşime girebildikleri ve başta dil-iletişim becerileri olmak üzere diğer becerilerde de gelişmeler edindikleri bilinmektedir (Goldstein ve Cisar, 1992; Sasso ve Rude, 1998). Özellikle sosyal becerilerindeki yetersizlikleri ile karakterize olan otizmli çocuklar, okul öncesi sınıflarındaki akranlarıyla olumlu ilişkiler geliştirdiklerinde, kaynaştırma programından yüksek verim alınabilmektedir. Uygulanan kaynaştırma eğitimlerinin, otizmli çocukların sosyal, duygusal gelişim alanlarında ilerleme sağladığı ve akran etkileşimleri sayesinde sosyalleşmelerinin kolay hâle geldiği bilinmektedir (Chamberlain, Kasari ve Fuller, 2007; Payne, 2010). Buna karşın, otizmli çocuklardaki bazı sosyal yetersizlikler (ilişki kurmada isteksiz olma, ifade edici dil becerilerindeki yetersizlikler, mimik ve jest kullanamama ve algılayamama vb.) sebebiyle akranlarıyla olumlu ilişkiler geliştirmedikleri, akranları tarafından yalnız bırakıldıkları ve dışlandıklarını saptayan çalışmalar da bulunmaktadır (Attwood, 2000; Bauminger ve Kasari, 2000; Menteş ve Aktaş Arnas, 2019).

Okul öncesi kaynaştırma sınıflarında bulunan otizmli çocuklarla ilgili alanyazında çeşitli çalışmalar bulunmakla beraber, bu çalışmaların genellikle otizmli çocukların sosyal becerilerini ve bu becerileri öğretim müdahalelerini (Aksoy, 2018; Balli, 2020; Dean, Adams ve Kasari, 2013; Girli ve Atasoy, 2010; Güven ve Diken, 2014; Laushey ve Heflin, 2000), sosyal 
iletişimlerini (Reichow ve Volkmar, 2010; White, Koenig ve Scahill, 2010), okula uyum ve etkileşim davranışlarını (Aksoy, 2018; Balli, 2020) incelediği görülmektedir. Son zamanlarda ise akran aracılı uygulamalar (Abbak Kaçar, 2019; Dean, Adams ve Kasari, 2013; Erdoğan, 2019; Ganz ve Flores, 2008; T1kıroğlu, 2019) göze çarpmaktadır. Ayrıca okul öncesi dönemdeki otizmli çocukların kaynaştırma sınıfındaki akran kültürü (Wolfberg, Zercher, Capell, Hanson ve Odom, 1999), oyun davranışlarını ve akran etkileşimlerini (Harper ve McCluskey, 2002; Jamero, 2019; Koagel, Koagel, Frea ve Fredeen, 2001; Sigman vd., 2020) inceleyen çalışmalara da ulaşılmıştır. Örneğin Wolfberg ve diğerleri (1999), aralarında otizmli çocukların da bulunduğu özel gereksinimli 10 okul öncesi çocuğunun akran kültürlerini, karma yöntem kullanarak (gözlem, aile ve öğretmen ile görüşme, Friendship Survey, doküman analizi, sosyometrik akran değerlendirmesi) araştırmışlardır. Çalışma sonucunda, özel gereksinimli çocukların akran kabulü görmek amacıyla akranlarına karşı çeşitli sosyal davranışlar gösterdikleri, fakat buna rağmen genel olarak akran kültüründen dışlandıkları görülmüştür.

Kaynaştırma sınıflarındaki akran ilişkilerine dair alanyazın incelediğinde çeşitli araştırmalar görülmekle beraber (Alptekin, 2010; Arslan, 2010; Çulhaoğlu İmrak ve Sığırtmaç, 2010; Diamond ve Hong 2010; Diamond ve Tu, 2009; Duman ve Koçak, 2013; İmrak, 2009; Kabasakal, Girli, Okun, Çelik ve Vardarl1, 2008; Küçüker, Erdoğan ve Çürük, 2014; Odom, Zercher, Li, Marquart, Sandall ve Brown, 2006; Sasso ve Rude, 1988), otizmli çocukların akran ilişkilerine dair araştırmaların yurtiçinde (Erol, 2012; Girli ve Atasoy, 2012; Metin, Şenol ve Yumuş, 2015) oldukça sınırlı olduğu görülmektedir. Örneğin Metin ve arkadaşları tarafindan (2015), okul öncesi kaynaştırma sınıflarındaki otizmli çocukların akran ilişkilerindeki konumu ve arkadaş olarak tercih edilme seviyeleri araştırılmış ve sonucunda bu çocukların hem sosyal hem de akademik açıdan farklı ortamlar içerisinde tercih edilme seviyelerinin oldukça az olduğu saptanmıştır. Ayrıca akran ilişkilerine yönelik çalışmalarda çoğunlukla nicel yöntemleri tercih edildiği (Bush ve Ladd, 2001; Erten, 2012; Ferreira, Aguiar, Correia, Fialho ve Pimentel, 2019; Metin vd., 2015; Ogelman ve Erten, 2013; Özmen, 2013; Sal1, 2014; Şen ve Özbey, 2017, Yoleri, 2015) görülmüştür. Örneğin Ferreira ve diğerlerinin (2019), özel gereksinimli çocukların kaynaştırma ortamındaki arkadaşlıklarını ve sosyal kabullerini incelediklerini araştırmada, Okul Öncesi Öğretmenleri için Sosyal Beceri Puanlama Sistemi (SSRS) ve sosyometrik akran değerlendirmesi kullanmışlardır. Literatürde akran ilişkilerinin incelenmesinde çoğunlukla nicel yöntemler kullanılmasına rağmen, akran ilişkilerinin ve sosyal yaşamın doğası gereği, çocuklardan doğrudan veri toplanması, davranışların doğal ortamda gözlenmesi, derinlemesine incelenmesi amacıyla nitel yöntemler önem taşımaktadır. Fakat son zamanlarda yapılan sınırlı sayıda çalışmada (Abbak Kaçar, 2019; Jamero, 2019; Menteş, Aktaş Arnas, 2019) nitel araştırma yöntemlerinin kullanıldığ 1 görülmektedir. Örneğin Jamero (2019), okul öncesi sınıfındaki otizmli çocukların akran-oyun etkileşimlerini incelemek amacıyla, oyun zamanında doğrudan gözlem yaparak incelemiştir. Çalışma sonucunda gözlemden elde edilen anekdotlarla, otizmli dokuz çocuğun, beş oyun kategorisinden dördünde yer aldığını, beşinci kategori olan karş11ıklı oyun altında hiçbir anekdot kategorize edilmediği saptanmıștır. Okul öncesi kaynaştırma sınıfındaki otizmli bir çocuğun akran ilişkilerini inceleyen bu araştırmada da, akran ilişkilerinin doğası gereği nitel araştırma yöntemlerine yer verilmiştir.

Literatürdeki araştırmalar, otizmli çocuklar ile ilgili çeşitli bilimsel verilere ulaşmıştır. Fakat, hem otizmli çocukların hem de okul öncesi sınıflarında kaynaştırma eğitimine katılma oranlarının gittikçe arttığı düşünüldüğünde, akran ilişkilerinin türüne ve niteliğine dair daha fazla araştırmaya ihtiyaç doğmuştur. Sınıflarda akran ilişkilerinin olumlu yönde geliştirilmesine yardımcı olacak durum betimlemeleri, hem öğretmenlerin farkındalığı arttıracak, hem de çocukların gelişimlerini desteklemek için yol gösterici olacaktır. Otizmli bir çocuğun okul öncesi kaynaştırma sınıfındaki akran ilişkilerini inceleyen bu çalışma, ilgili alanyazına katkı sağlayacak ve ileriki çalışmalara ışık tutacaktır. 
$\mathrm{Bu}$ araştırmanın amacı, otizmli bir çocuğun okul öncesi kaynaştırma sınıfındaki akranları ile ilişkilerinin incelenmesidir. Akran ilişkileri; akran kabulü, akran reddi ve zorbalığı olmak üzere üç boyut açısından incelenmiş ve aşağıdaki sorulara yanıt aranmıştır.

1. Otizmli bir çocuğun bulunduğu okul öncesi kaynaştırma sınıfındaki akran ilişkileri; akran kabulü, reddi ve zorbalığı davranışları açısından süreç içerisinde nasıl değişmektedir?

2. Kaynaştırma sınıfındaki normal gelişim gösteren çocukların, otizmli çocuğu akran reddi ve kabulü açısından tanımları süreç içerisinde nasıl değişmektedir?

3. Otizmli çocuğun, kaynaştırma sınıfındaki sosyal konumu süreç içerisinde nasıl değişmektedir?

\section{YÖNTEM}

Okul öncesi kaynaştırma sınıfındaki otizmli bir çocuğun akran ilişkilerinin incelenmesini amaçlayan bu çalışmada, davranışların karmaşık ve değişken yapısı, kaynaştırma eğitiminin doğal ortamı, bu bağlamın anlamlandırılması, betimlenmesi ve otizmli çocukların başlı başına özel bir olgu temsil etmesi sebebiyle nitel yaklaşımlardan betimsel durum çalışması olarak yürütülmüştür (Maxwell, 2008).

\section{1. Çalışma Grubu}

Bu araştırmanın katılımcılarını, 2019-2020 eğitim öğretim yılında, Adana ili Milli Eğitim Müdürlüğü'ne (MEM) bağlı bir anaokulunda, kaynaştırma sınıfındaki otizmli bir çocuk ve normal gelişim gösteren 21 çocuk oluşturmaktadır. Araştırmanın yapıldığı sınıf, hem otizmli çocuklarının okul öncesi kaynaştırma sınıflarında zor bulunurluğu hem de ekonomik açıdan uygun güzergâhta olması nedeniyle amaçlı örnekleme yöntemlerinden kolay ulaşılabilir durum örneklemesi ile seçilmiştir.

Araştırmanın katılımcı grubundaki, 60-72 ay aralığındaki 10 kız ve 11 erkek olmak üzere toplam 21 normal gelişim gösteren çocukların bir kısmı, bir önceki eğitim öğretim yılında da otizmli çocukla beraber eğitim görmüşlerdir dolayısıyla daha önceden birbirlerini tanımaktadırlar. Ayrıca sınıfta bir öğretmen bulunmakla beraber, haftanın bir günü meslek lisesi çocuk gelişimi ve eğitimi bölümü stajyeri uygulama öğrencisi gelmektedir. Otizmli çocuğun ebeveynleri, çocuğun özel durumunu herkesten gizli tutmak istemişlerdir. Dolayısıyla otizmli çocuk hakkında, sınıfta bulunan diğer çocuklara ve onların ebeveynlerine öğretmen tarafindan bilgilendirme yapılamamıştır.

Çalışmanın bir diğer katılımcısı olan otizmli çocuk, 2014 doğumlu bir kız çocuğudur. 4 yaşında atipik otizm olarak tanılanmıştır ve bu yaşından beri hem özel eğitim merkezine hem de anaokuluna tam zamanlı kaynaştırma şeklinde devam etmektedir. Otizmli katılımcı ifade edici dil becerilerinde zorluk yaşamaktadır, genellikle iki veya tek kelime kullanarak iletişim kurmaktadır. Alıcı dil becerileri ise yüksek seviyededir. İletişim sırasında ekolali sık görülmemekle beraber, gecikmiş ekolali görülmektedir. Sınıf içerisinde çoğunlukla evde duymuş olduğu sözleri tekrarlamaktadır. Birisi ona uyarıda bulunduğunda veya sesini yükselttiğinde gün boyu o uyarıları tekrarlamaktadır. Ayrıca saçlarını savurma, ayağını yere vurma, sürekli ayna karşısına gitme, tırnak yeme, farklı sesler çıkarma ve yüzünde ağlama ifadesi yapma gibi takıntılı ve tekrarlayıcı davranışları görülmektedir. $\mathrm{Bu}$ streotipik davranışların sıklığı dönem dönem değişiklik göstermektedir.

$\mathrm{Bu}$ araştırmada etik ilkeler kapsamında bazı önlemler alınmıştır. İlk olarak Çukurova Üniversitesi Sosyal Bilimler Enstitüsünden etik kurul onayı ve Adana MEM'den araştırmanın yapılmasına ilişkin onay alınmıştır. Ardından okul müdürü ve sınıftaki öğretmen ile görüşülmüş, izinler alınmış ve araştırma ile ilgili bilgilendirmeler yapılmıştır. Araştırmaya katılım gösteren çocukların ebeveynlerinden Aydınlatılmış Onam Formu hazırlanarak izinler alınmış ve bilgilendirmeler yapılmıştır. Çocuklara ise gelişimlerine uygun şekilde açıklama yapılmış ve 
sözlü onamları alınmıştır. Katılımcıların gizlilik ve mahremiyet hakları esas alınarak video ve ses kayıtlarının paylaşılmayacağına dair güvence sağlanmış, bilgileri korunmuş, bulgularda katılımcilara kodlar verilerek isimleri gizlenmiștir.

\subsection{Veri Toplama Araçları}

\subsubsection{Gözlem}

Bu çalışmada, gözlem aracılığıyla katılımcıların yaşantı, davranış, düşünce ve duygularıyla ilgili veri toplamak amaçlanmıştır. Nitel tasarlanan araştırmalarda genellikle, doğal ortam ve akış içerisinde, oldukça olabildiğince az yapılandırılmış gözlem yöntemi ile bir gruptan veri toplanması tercih edilmektedir (Punch, 2014). Bu çalışmada da yarı-yapılandırılmış gözlem tercih edilmiştir. Gözlemler 2019 yılının Eylül, Ekim, Kasım ve Aralık aylarında üçer kez yapılmıştır. Her bir gözlem, çocukların doğal etkileşimlerinin en yoğun olduğu oyun etkinlikleri sırasında yapılmış ve yaklaşık 45 dakika sürmüştür. Gözlem yapılırken araştırmacı odaklandığı davranış örüntülerini dikkatle gözlemlemiş ve sürekli olarak not almıştır. Aynı zamanda veri kaybını engellemek amacıyla süreç uzak açılı kamerayla da kayıt altına alınmıştır. Gözlem yapılırken odak katılımcı otizmli çocuk ve akranlarına karşı davranışları olmak üzere, otizmli çocukla iletişime geçen ve etkileşim gösteren tüm akranların verileri kayıt altına alınmıştır.

Yapılan çalışmada ön yargı ve öznellik gibi durumları kontrol altına almak amacıyla araştırmacı, katılımcı olmayan gözlemci rolünü benimsemiş ve çocukların arasına dâhil olmamıştır.

\subsubsection{Görüșme}

Araştırmanın gerçekleștirildiği bağlam içerisinde, odaklanılan durumla ilgili bilgi, kavram, deneyim ve görüşler, etkileşimler ve anlamlandırmalara ulaşmak, davranış ve düşünceler arasında bir bağlantı kurabilmek amacıyla bu araştırmada görüşme yöntemi tercih edilmiştir (Mason, 1996; Seidman, 1991). Normal gelişim gösteren çocuklarla, çiz-anlat ve sosyometri teknikleri kullanılarak görüşmeler gerçekleştirilmiştir.

Çiz-Anlat Tekniği: Araştırmada, akran ilişkilerine dair bilgi edinmek ve ortamı daha iyi algılamak, normal gelişim gösteren çocukların otizmli çocukla ilişkisini ve onun hakkındaki duygu, düşünceleri rahat ifade etmesi amaciyla çiz-anlat tekniği kullanmıştır. Çocukların öncelikle bir olgu, olay veya durumla ilgili resim çizmesi ve daha sonra çizimlerin anlatılmasını içeren bu teknik ile beraber, çocukların düşünceleri ve algıları açığa çıkarmak amaçlanmaktadır (Pridmore ve Bendelow, 1995; Sewell, 2011). Yapılan bu araştırmada da ilk olarak sınıftaki her çocuğa, otizmli çocuğun ve kendisinin olduğu bir resim çizmesi talep edilmiştir. Çocukların çizdikleri resimleri anlatmasının ardından, otizmli çocukla ilişkilerine dair toplam dört soru yöneltilmiştir. Çiz-anlat tekniği, dönem başı ve sonu olmak üzere iki kez uygulanmıştır.

Sosyometri Tekniği: Sosyometri tekniği, bir grupta bulunan bireylerin sosyal etkileşimlerini ve sosyal konumlarını, ilişkilerini betimlemek amaciyla kullanılmaktadır (Morgan, 1988). Bu teknik ile beraber popüler, dışlanan (ihmal edilen), reddedilen, ortalama ve tartışmalı olarak beş ayrı sosyal konum çeşidi saptanmaktadır (Gülay, 2010). Bu araştırmada, akran ilişkilerine yönelik farklı bakış açısı elde etmek, grup dinamikleri ve otizmli çocuğun sosyal statüsünü incelemek amacıyla sosyometri tekniği kullanmıştır. Bu teknik, çocuğun konumunun uyum süreci sonrasına değișebileceği olasıllı̆ı göz önüne alınarak, dönem başı ve sonu olmak üzere (2019 Ekim ve Ocak) iki kere uygulanmıştır. Çalışmada, her bir çocuğa ilk olarak çocukların fotoğraflarının olduğu bir materyal gösterilmiş ve oyun oynamayı tercih ettikleri üç arkadaşına sırayla gülen yüz, daha sonra oyun oynamayı tercih etmediği üç arkadaşına üzülen yüz ifadesi içeren kart koymaları istenilmiştir. Ayrıca bu sosyometri uygulamasında otizmli çocuğa kart koyan çocuklara, "Neden onunla oynamayı seviyorsun? Anlatır mısın?, Arkadaşınla sınıfta birlikte neler yapıyorsunuz?" veya "Neden onunla oynamayı sevmiyorsun?, Arkadaşın sınıfta neler yapıyor?" soruları yöneltilmiştir. 
Elde edilen veriler, bilgisayar ortamında z puanına dönüştürülmüş, çocukların sevilme (L) ve sevilmeme (D) puanları hesaplanmıştır. Z puanı ham puandan aritmetik ortalamanın çıkarılması ve bunların standart sapmaya bölünmesi ile elde edilmiştir. Bu işlem hem sevilme hem de sevilmeme puanları için hesaplanmıştır. Ardından her çocuk için Sosyal Etki (SI) ve Sosyal Tercih (SP) puanı bulunmuştur. Sosyal tercih sevilme ve sevilmeme puanları arasındaki farkla, sosyal etki ise bunların toplamı ile hesaplanmıştır (Coie ve diğerleri, 1982, Akt: Kaya, 2005). Sosyal konum ve statü belirlenirken kullanılan ölçütler:

$\mathrm{SP}>1,0 ; \mathrm{L}>\mathrm{O}, \mathrm{D}<\mathrm{O}$ ise popüler,

$\mathrm{SP}<-1,0 ; \mathrm{L}<\mathrm{O}, \mathrm{D}>\mathrm{O}$ ise reddedilen,

$\mathrm{SI}<-1,0 ; \mathrm{L}<\mathrm{O}, \mathrm{D}<\mathrm{O}$ ise ihmal edilen (dışlanan),

$\mathrm{SI}>1,0 ; \mathrm{L}>\mathrm{O}, \mathrm{D}>\mathrm{O}$ tartışmalıdır.

SP (sosyal tercih) puanı $-0,5$ ile $+0,5$ ve SI (sosyal etki) puan1 $-0,5$ ile $+0,5$ arasında ise ortalama sosyometrik statü grubudur. Bu sinıflama dâhilinde hiçbir gruba girmeyen çocuklar da "Diğerleri" olarak gruplandırılmıştır (Kaya, 2005).

\subsection{Verilerin Analizi}

Araştırmanın verileri, 480 dakikalık video kayıtları, gözlem notları, normal gelişim gösteren çocuklar tarafından çizilen 43 adet resim, sınıfin fiziksel ortamına dair fotoğraflar, sosyometri sırasında alınan notlar ve görüşmelerden elde edilen ve bilgisayar ortamına aktarılan 71 sayfa metinden oluşmaktadır. Veri toplama sürecinde, aynı zamanda düzenli olarak elde edilen veriler içerik analizi yöntemi ile çözümlenmiştir. Düzenli bir şekilde bilgisayar ortamına geçirilen gözlem notları kodlanmış ve her ay için ayrı içerik analizleri yapılmışıı. Ay sonunda kodlar toplu şekilde okunmuş ve kategoriler oluşturulmuştur. Kod dosyaları incelenmiş ve aynı kategoride olabilecek kodlar birleştirilmiş ve bir yerde toplanmıştır. Kategorilere toplu şekilde bakılmış ve ana kategoriler ve alt kategoriler oluşturulmuştur. Kategoriler oluşturulduktan sonra ait oldukları temalara yerleştirilmiştir. Her ay sonunda önceki aya tekrar dönülmüş ve gerekli kontroller yapılmış ve okunmuştur.

Çalışmada geçerlik ve güvenirliğini sağlamak amacıyla, farklı veri toplama yöntemleri ile veriler toplanılarak üçgenleme yapılmıştır. Ayrıca analiz sürecinde ek kodlayıcı kullanılarak tutarlılık incelenmiştir. Kodlayıcılar arası güvenilirlik, uzlaşılan kodların, uzlaşılmayan ve uzlaşılan kodların toplamına bölünerek hesaplanmış ve \% 78,3 bulunmuştur. Nitel çalışmalarda ek kodlayıcılar arası güvenirliğin \%80 civarı olması olması gerektiği bilinmektedir (Miles ve Huberman, 1994).

\section{BULGULAR}

Araştırmanın amacı kapsamında, hem otizmli çocuğun akranlarına karşı, hem de normal gelişim gösteren çocukların otizmli çocuğa karşı davranışları incelenmiş ve bu davranışların süreç içerisindeki değişimine bakılmıştır. Ayrıca normal gelişim gösteren çocukların otizmli çocuğu nasıl tanımladıkları, otizmli çocuğun sosyal konumu incelenmiş ve bulgular aşağıda sunulmuştur.

Bulgular sunulurken etik açıdan araştırmaya katılan çocukların isimleri kullanılmamış olup bunun yerine normal gelişim gösteren çocuklar $\mathrm{N}$ harfi ile numaralandırılmış, otizmli çocuk ise Ö sembolü ile gösterilmiştir. Davranışın görüldüğü aylar Eylül (1), Ekim (2), Kasım (3) ve Aralık (4) şeklinde kodlanmıştır. Davranış sıklığı ise o kategorilere ait kodların görülme sayısı toplanıp elde edilmiştir.

3.1. Otizmli Bir Çocuğun Bulunduğu Okul Öncesi Kaynaştırma Sınıfındaki Akran İliş̧ilerinin; Akran Kabulü, Reddi ve Zorbalığı Davranışları Açısından Süreç İçerisindeki Değişime Dair Gözlem Bulguları 
Bu bölümde gözlemlerden elde edilen, otizmli çocuğun sınıfındaki akranlarına karşı akran kabulü, akran reddi ve akran zorbalığı davranışları (Tablo 1, 2, 3) ve normal gelişim gösteren çocukların otizmli çocuğa karşı akran kabulü, reddi ve zorbalığı davranışları (Tablo 4, 5, 6) süreç içerisinde ayrı ayrı incelenmiş ve tablolar hâlinde sunulmuştur.

Otizmli çocuğun okul öncesi kaynaştırma sınıfındaki akran kabulü davranışları Tablo 1'de sunulmuştur.

Tablo 1. Otizmli Çocuğun Okul Öncesi Kaynaştırma Sınıfındaki Akran Kabulü Davranışları

\begin{tabular}{|c|c|c|c|c|}
\hline Tema & Kategori & Alt Kategori & $\begin{array}{l}\text { Davranışın } \\
\text { görüldüğü } \\
\text { aylar }\end{array}$ & $\begin{array}{l}\text { Davranışı } \\
\text { n görülme } \\
\text { sıklığı }\end{array}$ \\
\hline \multirow{9}{*}{$\begin{array}{l}\text { Akranlarına } \\
\text { İlgi } \\
\text { Davranışları }\end{array}$} & \multirow[b]{2}{*}{$\begin{array}{l}\text { Pasif İlgi } \\
\text { Gösterme }\end{array}$} & Oyun oynayan arkadaşlarını yakından izleme & $1,2,3,4$ & 64 \\
\hline & & Oyun oynayan arkadaşlarını uzaktan izleme & $1,2,3,4$ & 95 \\
\hline & \multirow{7}{*}{$\begin{array}{l}\text { Aktif İlgi } \\
\text { Gösterme }\end{array}$} & Arkadaşının yanına gitme & $1,2,3$ & 13 \\
\hline & & Arkadaşıyla sözlü iletişim başlatma & $1,2,3,4$ & 36 \\
\hline & & Oyun oynayan arkadaşının yanına oturma & 1,2 & 4 \\
\hline & & Arkadaşına gülümseme & $1,2,3,4$ & 37 \\
\hline & & Arkadaşına fiziksel temas etme & 2 & 5 \\
\hline & & Arkadaşına öneride bulunma & 3 & 2 \\
\hline & & Arkadaşına soru yöneltme & 4 & 4 \\
\hline \multirow{9}{*}{$\begin{array}{l}\text { Akranlarıyla } \\
\text { Birliktelik } \\
\text { Davranışları }\end{array}$} & \multirow{9}{*}{$\begin{array}{l}\text { Oyun Oynama } \\
\text { Davranışları }\end{array}$} & Arkadaşlarıyla dramatik oyun sürdürme & $1,2,3,4$ & 9 \\
\hline & & Arkadaşıyla manipülatif oyun oynama & $1,2,3$ & 17 \\
\hline & & $\begin{array}{l}\text { Arkadaşlarıyla merkezlerde paralel oyun } \\
\text { oynama }\end{array}$ & $1,2,3,4$ & 15 \\
\hline & & Tek başına materyal ile oynama & $1,2,3,4$ & 71 \\
\hline & & $\begin{array}{l}\text { Arkadaşlarına materyal gösterme ve hakkında } \\
\text { konuşma }\end{array}$ & $1,2,3,4$ & 26 \\
\hline & & Arkadaşlarıyla materyal alışverişi yapma & $1,2,3,4$ & 7 \\
\hline & & Materyali arkadaşına dokundurma & 2 & 3 \\
\hline & & Arkadaşının materyalini inceleme & 2,3 & 7 \\
\hline & & Arkadaşından materyal isteme & 2 & 4 \\
\hline
\end{tabular}

Tablo 1 incelendiğinde, otizmli çocuğun akran kabulü davranışlarının akranlarına ilgi davranışları ve akranlarıyla birliktelik davranışları olmak üzere iki tema altında toplandığı görülmektedir. 
Akranlarına ilgi davranışları temasında, oyun oynayan arkadaşlarını uzaktan izleme ve yakından izleme davranışları dikkat çekmiştir. Otizmli çocuk, sınıf içerisinde çoğu vaktini oturarak uzaktan arkadaşlarını izlemekle (95) geçirmiştir. Arkadaşına gülümseme (37) davranışı aktif ilgi gösterme kategorisinde en çok görülen davranış olmuştur. Sözlü iletişim başlatma (36) genelde tek kelimeyle oluşmuştur ve devam ettirmede sorun yaşadığı görülmüştür. Bu sorun ya karş1 tarafın cevap vermemesinden ya da çocuğun iletişimi devam ettirememesinden kaynaklanmıştır. Arkadaşına soru sorma ise alakasız konulardan oluşmaktadır. Örneğin durduk yere, arkadaşı resim yaparken yanına gelip, "Acıdı mı?” diye sormuştur. Bu durum, çocuğun daha önce yaşadıklarını-duyduklarını gecikmiş ekolali olarak gerçekleştirdiği şeklinde yorumlanmıştır.

Akranlarıyla birliktelik davranışları temasında; otizmli çocuğun oyun oynama davranışlarına bakıldığında, dramatik oyun sürdürme, arkadaşlarıyla merkezlerde paralel oyun oynama ve arkadaşıyla manipülatif oyun oynama davranışlarının kısa süreli olduğu ve verimsiz olduğu ortaya konmuştur. Tek başına materyalle oyun oynama ise dört ay boyunca (71) en çok görülen alt kategori olmakla beraber diğerler oynama davranışlarına kıyasla daha uzun sürelidir. Ayrıca otizmli çocuk tek başına materyal ile oyun oynarken genellikle bir oyuncak bebek veya bloklarla oyun oynamayı tercih etmiştir.

Otizmli çocuk etkileşim başlatabilmekte fakat devam ettirmekte zorluk yaşamaktadır. Kısa süreli birliktelikler gözlemlenmekte fakat sosyal iletişim çok çabuk kesintiye uğramaktadır. Sosyal iletişimdeki kesintilere otizmli çocuğun yanı sıra normal gelişim gösteren akranlarının da neden olabileceği belirlenmiştir. Ayrıca bu kesintilerden sonra otizmli çocuğun örnekte olduğu gibi kendini sıkma gibi davranışlar veya tekrarlayıcı davranışlar sergilediği görülmüştür:

Ö, erkek arkadaşının yanına bebek alıp geldi ve "hastaneye gittiler" dedi. Arkadaşı bir diğer arkadaşına döndü ve "Ö hastaneye gittiler diyor" dedi. Ö bebeği başka bir erkek arkadaşına getirdi ve değdirdi. Bir kiz arkadaşı elinden bebeği aldı. Ö bunun üzerine erkek arkadaşının yanına gitti ve koluna dokundu. Arkadaşı tepki vermedi. Ö kolların sıkıp köşede, ağzını açtı ve kendini sıktı (15.10.2019).

Otizmli çocuğun akran reddine dair davranışlar Tablo 2' de sunulmuştur.

Tablo 1. Otizmli Çocuğun Okul Öncesi Kaynaştırma Sınıfındaki Akran Reddi Davranışları

\begin{tabular}{|c|c|c|c|c|}
\hline Tema & Kategori & Alt Kategori & $\begin{array}{l}\text { Davranışın } \\
\text { görüldüğü } \\
\text { aylar }\end{array}$ & $\begin{array}{c}\text { Davranışın } \\
\text { görülme } \\
\text { sıklığ1 }\end{array}$ \\
\hline \multirow{8}{*}{$\begin{array}{l}\text { Akranlarına } \\
\text { Karşı İlgisiz } \\
\text { Davranışlar }\end{array}$} & & Sınıfın tenha köşelerinde vakit geçirme & $1,2,3,4$ & 42 \\
\hline & $\begin{array}{l}\text { Ortamdan } \\
\text { Uzaklaşma } \\
\text { Davranışları }\end{array}$ & Tenha köşelerde saklanma & 1 & 6 \\
\hline & \multirow{6}{*}{$\begin{array}{l}\text { Arkadaşlarından } \\
\text { Uzaklaşma } \\
\text { Davranışları }\end{array}$} & Arkadaşlarından uzağa oturma & $1,2,3,4$ & 21 \\
\hline & & Arkadaşının yanından uzaklaşma & $1,2,3$ & 9 \\
\hline & & $\begin{array}{l}\text { Fiziksel temas gösteren arkadaşından } \\
\text { uzaklaşma }\end{array}$ & 1,2 & 3 \\
\hline & & Sözel iletişime cevap vermeme & $1,2,3,4$ & 22 \\
\hline & & Sözel iletişimi devam ettirmeme & 1 & 3 \\
\hline & & Öğretmenin yönergesini görmezden gelme & 2,3 & 7 \\
\hline
\end{tabular}




\begin{tabular}{|c|c|c|c|c|}
\hline \multirow{3}{*}{$\begin{array}{l}\text { Akranlarıyla } \\
\text { Uyumsuz } \\
\text { Davranışlar }\end{array}$} & \multirow[t]{2}{*}{$\begin{array}{l}\text { Pasif Uyumsuz } \\
\text { Davranışlar }\end{array}$} & \multirow[b]{2}{*}{ Arkadaşının oyuna davetine yanıt vermeme } & \multirow[b]{2}{*}{3} & \multirow[b]{2}{*}{2} \\
\hline & & & & \\
\hline & \multirow{9}{*}{$\begin{array}{l}\text { Otizme Bağlı } \\
\text { Uyumsuz } \\
\text { Davranışlar }\end{array}$} & Otizme bağlı uzun süre nesnelerle ilgilenme & $1,2,3,4$ & 35 \\
\hline & & Sınıfta uzun süre oturma & $1,2,3,4$ & 49 \\
\hline & & Sınıfta amaçsız dolaşma & $1,2,3,4$ & 13 \\
\hline & & Uygunsuz davranışlar sergileme & $1,2,3,4$ & 9 \\
\hline & & Kendi kendine konuşma & $1,2,3,4$ & 98 \\
\hline & & Kendiyle ilgilenme & 3,4 & 42 \\
\hline & & Eliyle ağzını kapama & 3 & 25 \\
\hline & & Kendi kendine sus işareti yaparak kızma & 2 & 2 \\
\hline & & Tekrarlı olarak nesneyi gösterme & 2 & 9 \\
\hline & & Ağlama & $1,2,3$ & 24 \\
\hline & $\begin{array}{l}\text { Aktif Uyumsuz } \\
\text { Davranışlar }\end{array}$ & Öğretmenine arkadaşını şikâyet etme & 2 & 2 \\
\hline
\end{tabular}

Tablo 2 incelendiğinde, akranlarına ilgisiz davranışlar ve akranlarıyla uyumsuz davranışlar olmak üzere iki tema oluştuğu görülmektedir.

Akranlarına ilgisiz davranışlar temasında, ortamdan uzaklaşma kategorisinden "sınıfın tenha köşelerinde vakit geçirme" dört aylık gözlemlerin tamamında bulunmaktadır ve davranışın görülme sıklığı da yüksektir (42). Akranlarıyla uyumsuz davranışlar temasında, pasif uyumsuz davranışlar kategorisinde sadece sözel iletişime cevap vermeme, sözel iletişimi devam ettirmeme alt kategorileri ilk ay gözlemlenmiş olup, öğretmenin yönergesini görmezden gelme ve arkadaşının oyuna davetine yanıt vermeme davranışları ilk aydan sonra oluşmuştur. Sözel iletişime cevap vermeme alt kategorisi dört aylık gözlemlerin tamamında görülmüsşür.

Uygunsuz davranışlar sergileme kategorisi, burnunu karıştırma, eteğini açma, oyuncağı eteğinin altına koyma, göbeğini açma gibi davranışlardan oluşmaktadır. Otizme bağlı uyumsuz davranışlardan; otizme bağlı uzun süre nesnelerle ilgilenme, sınıfta uzun süre oturma, sınıfta amaçsız dolaşma, kendi kendine konuşma ve uygunsuz davranışlar sergileme kategorileri dört ay boyunca devam etmiş ve yoğun şekilde gözlemlenmiştir. Diğer kategoriler ise (kendiyle ilgilenme, eliyle ağzını kapama, kendi kendine sus işareti yaparak kızma, tekrarlı olarak nesneyi gösterme) ilk ayda gözlenmezken, diğer aylarda ortaya çıkmıştır.

Otizmli çocuğun akran zorbalığına dair davranışlar Tablo 3'te sunulmuştur. 
Tablo 2. Otizmli Çocuğun Okul Öncesi Kaynaştırma Sınıfındaki Akran Zorbalığı Davranışları

\begin{tabular}{|c|c|c|c|c|}
\hline Tema & Kategori & Alt Kategori & $\begin{array}{c}\text { Davranışın } \\
\text { görüldüğ̈̈ aylar }\end{array}$ & $\begin{array}{l}\text { Davranışın } \\
\text { görülme } \\
\text { sıklığı }\end{array}$ \\
\hline \multirow{15}{*}{$\begin{array}{l}\text { Akranlara } \\
\text { Karşı } \\
\text { Zorbalık } \\
\text { Davranışla } \\
\text { rı }\end{array}$} & & Ayağını yere vurma & $1,2,3,4$ & 12 \\
\hline & $\begin{array}{l}\text { Otizme Bağlı } \\
\text { Zorbalık }\end{array}$ & Kendine zarar verme & $1,2,3,4$ & 119 \\
\hline & Davranışları & Kendi kendine bağırma & $1,2,3,4$ & 21 \\
\hline & & $\begin{array}{l}\text { Yüzüne ağlama ifadesi yaparak } \\
\text { arkadaşını korkutma }\end{array}$ & 2,3 & 13 \\
\hline & & Arkadaşına sus işareti yaparak kızma & 3 & 6 \\
\hline & & Sınıfa bağırma & 1,4 & 5 \\
\hline & \multirow{9}{*}{$\begin{array}{l}\text { Doğrudan } \\
\text { Zorbalık } \\
\text { Davranışları }\end{array}$} & $\begin{array}{l}\text { İzinsiz arkadaşlarının materyalleri ile } \\
\text { oynama }\end{array}$ & 1 & 3 \\
\hline & & Arkadaşına fiziksel şiddet uygulama & 2,3 & 7 \\
\hline & & Arkadaşına sözel şiddet uygulama & $2,3,4$ & 9 \\
\hline & & Arkadaşına vuruyormuş gibi yapma & 2 & 4 \\
\hline & & Arkadaşına materyal firlatma & 2 & 3 \\
\hline & & Arkadaşına suç atma & 2 & 3 \\
\hline & & Nesnelere zarar verme & 3,4 & 16 \\
\hline & & Arkadaşına rahatsız edici yaklaşma & 3 & 8 \\
\hline & & Arkadaşının materyaline zarar verme & 2 & 2 \\
\hline
\end{tabular}

Tablo 3'e genel olarak bakıldığında, ilk ay sadece ayağını yere vurma, kendine zarar verme, kendi kendine bağırma, izinsiz arkadaşlarının materyalleri ile oynama ve sınıfa bağırma olmak üzere beş alt kategori görülürken, süreç içerisinde bunlara ek olarak tablodaki diğer 10 davranış görülmeye başlanmıştır. Ayrıca tabloda en dikkat çeken, kendine zarar verme (119) alt kategorisinin diğerlerine kıyasla çok daha fazla görülmesi olmuştur. Kendine zarar verme davranışı genelde tırnaklarını yeme, 1sırma gibi kodlardan oluşmaktadır. Nesnelere zarar verme davranışı sandalyeye vurma, kapıya vurma gibi davranışları içerirken, arkadaşının materyaline zarar verme davranışı resim kâğıdını karalama gibi davranışları içermektedir. Arkadaşına rahatsız edici yaklaşma davranışı ise genelde yüzüne ağlama ifadesi yaparak, ağzını açıp arkadaşının yüzüne yaklaştırma davranışından oluşmaktadır. Aşă̆ıdaki örnekte arkadaşına rahatsız edici yaklaşma ve sözel şiddet davranışı göze çarpmaktadır:

Ö aynada ağlama ifadesi yaparak kendine baktı. Bir arkadaşına gidip yüzüne bakarak ă̆lama ifadesi yaptt. Çocuk korktu ve kalktt. Öğretmen çocuğa "tedirgin olma" dedi. Çocuk yerine oturmaya çalıştı ama Ö onun yolunu kesti. Ağzını açarak yaklaştı. Çocuk tepki vermedi, sonra kalktı. Ö arkadaşına yaklaşıp "Senin ăgzını kırarım." dedi (15.10.2019).

Okul öncesi kaynaştırma sınıfındaki normal gelişim gösteren çocukların, otizmli çocuğa karşı akran kabulü davranışları Tablo 4'te sunulmuştur. 
Tablo 4. Okul Öncesi Kaynaştırma Sınıfındaki Çocukların, Otizmli Çocuğa Karşı Akran Kabulü Davranışları

\begin{tabular}{|c|c|c|c|c|}
\hline Tema & Kategori & Alt Kategori & $\begin{array}{c}\text { Davranışın } \\
\text { görüldüğü } \\
\text { aylar }\end{array}$ & $\begin{array}{c}\text { Davranışın } \\
\text { görülme sıklığ }\end{array}$ \\
\hline \multirow{15}{*}{$\begin{array}{l}\text { Otizmli } \\
\text { Çocuğa İlgi } \\
\text { Davranışları }\end{array}$} & \multirow{6}{*}{$\begin{array}{l}\text { Pasif İlgi } \\
\text { Gösterme }\end{array}$} & Otizmli Çocuğa Yaklaşma & $1,2,3,4$ & 48 \\
\hline & & Otizmli Çocuğu İzleme & $1,2,4$ & 15 \\
\hline & & $\begin{array}{l}\text { Arkadaşlarıyla çocuk hakkında } \\
\text { konuşma }\end{array}$ & 1,2 & 7 \\
\hline & & Gülümseme & $2,3,4$ & 8 \\
\hline & & Şiddeti görmezden gelme & 2 & 9 \\
\hline & & Otizmli çocuğun yanına oturma & 3 & 10 \\
\hline & \multirow{9}{*}{$\begin{array}{l}\text { Aktif İlgi } \\
\text { Gösterme }\end{array}$} & Oyuna davet etme & $1,2,3,4$ & 28 \\
\hline & & Sözlü iletişim başlatma & $1,2,3,4$ & 21 \\
\hline & & Fiziksel temasta bulunma & $1,2,3,4$ & 45 \\
\hline & & Otizmli çocuğa oyun kurgulama & 2 & 12 \\
\hline & & Otizmli çocuğu yanına çağırma & $2,3,4$ & 10 \\
\hline & & Otizmli çocuğa öneride bulunma & 2 & 6 \\
\hline & & Otizmli çocuğa soru yöneltme & $2,3,4$ & 12 \\
\hline & & $\begin{array}{l}\text { Otizmli çocuğu diğer } \\
\text { arkadaşlarına yönlendirme }\end{array}$ & 2 & 2 \\
\hline & & $\begin{array}{l}\text { Otizmli çocuğun oyununa dahil } \\
\text { olma }\end{array}$ & 3 & 5 \\
\hline \multirow{7}{*}{$\begin{array}{l}\text { Otizmli } \\
\text { Çocukla } \\
\text { Uyumlu } \\
\text { Davranışlar }\end{array}$} & \multirow{7}{*}{$\begin{array}{l}\text { Yardımlaşma } \\
\text { Davranışları }\end{array}$} & Otizmli çocuğa materyal verme & 2,3 & 18 \\
\hline & & $\begin{array}{l}\text { Otizmli çocuğun öz bakım } \\
\text { becerilerine yardım etme }\end{array}$ & 2 & 7 \\
\hline & & Otizmli çocuğu yönlendirme & $1,2,3,4$ & 9 \\
\hline & & $\begin{array}{l}\text { Otizmli çocuğa nesnelerle ilgili } \\
\text { açıklama yapma }\end{array}$ & 2,4 & 3 \\
\hline & & Çocuğun hakkını savunma & 4 & 8 \\
\hline & & Çocuğa akademik yardım etme & 4 & 4 \\
\hline & & Yaşanan problemi çözme çabası & 2 & 2 \\
\hline
\end{tabular}

Tablo 4 incelendiğinde, otizmli çocuğa karşı ilgili davranışları ve otizmli çocukla uyumlu davranışlar olmak üzere iki tema olduğu görülmektedir. Tabloya bakıldığında, pasif ilgi gösterme 
davranışlardan otizmli çocuğa yaklaşma davranışı (48) en çok görülen davranış olmakla beraber, dört ay boyunca gözlemlenmiştir. Ayrıca buna ek olarak otizmli çocuğu izleme, arkadaşlarıyla çocuk hakkında konuşma ilk ay görülmüş olup; diğer üç davranış (gülümseme, şiddeti görmezden gelme, otizmli çocuğun yanına oturma) birinci aydan sonra gözlenmeye başlanmıştır. Aktif ilgi gösterme davranışlarından sadece üçü (oyuna davet etme, sözlü iletişim başlatma, fiziksel temasta bulunma) ilk ay görülmüş ve diğer tüm aylarda düzenli şekilde görülmüşlerdir. Diğer altı aktif ilgi gösterme davranışı ise ilk aydan sonra ortaya çıkmıştır. Bu kategoride dikkat çeken, fiziksel temasta bulunma (45) alt kategorisinin en çok görülen davranış olmasıdır. Yardımlaşma davranışlarından otizmli çocuğu yönlendirme tüm aylarda gözlemlenmiştir. Ayrıca çocuğun hakkını savunma ve çocuğa akademik yardım etme gibi pro sosyal davranışlar dördüncü ay itibariyle görülmüştür.

Bu çocukların otizmli çocuğa karşı akran reddi davranışları Tablo 5'te sunulmuştur.

Tablo 3. Okul Öncesi Kaynaştırma Sınıfındaki Çocukların, Otizmli Çocuğa Karşı Akran Reddi Davranışları

\begin{tabular}{|c|c|c|c|c|}
\hline Tema & Kategori & Alt Kategori & $\begin{array}{l}\text { Davranışın } \\
\text { görüldüğü aylar }\end{array}$ & $\begin{array}{c}\text { Davranışın } \\
\text { görülme } \\
\text { sıklığı }\end{array}$ \\
\hline \multirow{6}{*}{$\begin{array}{l}\text { Otizmli } \\
\text { Çocuğa Karşı } \\
\text { İlgisiz } \\
\text { Davranışlar }\end{array}$} & \multirow{3}{*}{ Tepkisizlik } & Çocuğun iletişimine yanıt vermeme & $1,2,3,4$ & 22 \\
\hline & & Çocuğun yaptıklarına tepki vermeme & $1,2,3,4$ & 16 \\
\hline & & Otizmli çocuğa bakmama & 3 & 6 \\
\hline & \multirow{3}{*}{ Uzaklaşma } & Çocuğun bulunduğu yerden uzaklaşma & $1,2,3,4$ & 29 \\
\hline & & Çocuğu uzaklaştırmaya çalışma & 2,3 & 10 \\
\hline & & $\begin{array}{l}\text { Arkadaşını otizmli } \\
\text { çocuktanuzaklaştırma }\end{array}$ & 2 & 2 \\
\hline \multirow{4}{*}{$\begin{array}{l}\text { Otizmli } \\
\text { Çocukla } \\
\text { Uyumsuz } \\
\text { Davranışlar }\end{array}$} & \multirow{4}{*}{$\begin{array}{l}\text { Kabullenmeme } \\
\text { Davranışları }\end{array}$} & Engel olma & 2 & 3 \\
\hline & & Garip bulma & 2 & 7 \\
\hline & & Küçümseme & 4 & 4 \\
\hline & & Materyal paylaşmama & 2,3 & 8 \\
\hline
\end{tabular}

Tablo 5 incelendiğinde, çocukların akran reddi davranışları, otizmli çocuğa karşı ilgisiz davranışlar ve otizmli çocukla uyumsuz davranışlar olmak üzere ikiye ayrılmıștır. Tablo incelendiğinde üç davranışın (çocuğun iletişimine yanıt vermeme, çocuğun yaptıklarına tepki vermeme, çocuğun bulunduğu yerden uzaklaşma) ilk aydan itibaren gözlendiği; diğer yedi davranışın ise sonraki aylarda görülmeye başlandığı saptanmıştır. En çok görülen akran reddi davranışının ise çocuğun bulunduğu yerden uzaklaşma (29) olduğu görülmüştür. Normal gelişim gösteren çocukların otizmli çocuğa karşı ilgisiz davranışlarından tepkisizlik kategorisinde; çocuğun iletişimine yanıt vermeme (22) en sık görülen alt kategori olmuştur.

Otizmli çocukla uyumsuz davranışlar; çocukların otizmli çocuğu aralarından biri olarak görmedikleri, onunla uyum içerisinde olamadıkları davranışları içermektedir. Engel olma, garip bulma, küçümseme ve materyal paylaşmama alt kategorileri elde edilmiştir. Bu kategorideki davranışlar ilk ay hiç gözlemlenmemiştir. İkinci ay itibariyle davranışlar görülmeye başlanmıştır. Garip bulma davranışına dair bir örnek; 
Ö tekrar arkadaşına durduk yere "bir daha duymayacağım" dedi. Arkadaşı cevap vermedi. Diğer arkadaşlarıyla bakışıp Ö'ye güldüler. "Tuvalete karışma” dedi bir diğer arkadaşına Ö. Arkadaşı "tuvalete karışma diyor" dedi diğer arkadaşlarına ve dudaklarını büzdüler (15.10.2019).

Sınıftaki normal gelişim gösteren çocukların otizmli çocuğa karşı akran zorbalığ davranışları Tablo 6'da sunulmuştur.

Tablo 6. Okul Öncesi Kaynaştırma Sınıfindaki Çocukların, Otizmli Çocuğa Karşı Akran Zorbalığı Davranışları

\begin{tabular}{|c|c|c|c|c|}
\hline Tema & Kategori & Alt Kategori & $\begin{array}{c}\text { Davranışın } \\
\text { görüldüğü aylar }\end{array}$ & $\begin{array}{l}\text { Davranışın } \\
\text { görülme } \\
\text { sıklığ1 }\end{array}$ \\
\hline \multirow{9}{*}{$\begin{array}{l}\text { Otizmli } \\
\text { Çocuğa Karşı } \\
\text { Zorbalık } \\
\text { Davranışları }\end{array}$} & \multirow{5}{*}{$\begin{array}{l}\text { Dolaylı } \\
\text { Saldırgan Davranışlar }\end{array}$} & Materyali izinsiz alma & $1,2,4$ & 10 \\
\hline & & Kaşlarını çatma & 2 & 4 \\
\hline & & Çocuğun oyununu bozma & 4 & 5 \\
\hline & & Suça teşvik etme & 2 & 2 \\
\hline & & Suç atma & 3,4 & 4 \\
\hline & \multirow{4}{*}{$\begin{array}{l}\text { Doğrudan Saldırgan } \\
\text { Davranışlar }\end{array}$} & Sözel şiddet uygulama & $1,2,3,4$ & 21 \\
\hline & & Alay etme & 1,2 & 24 \\
\hline & & Tehdit etme & 2 & 4 \\
\hline & & Fiziksel şiddet uygulama & $2,3,4$ & 9 \\
\hline
\end{tabular}

Tablo 6 genel olarak incelendiğinde; materyali izinsiz alma, sözel şiddet uygulama ve alay etme davranışları birinci aydan itibaren gözlenmiş, diğer altı davranış ise sonraki aylarda görülmeye başlanmıştır. Bu davranışlardan en dikkat çeken, alay etme (24) kategorisinin ilk iki ay en sık görülen davranış olduğu ve bunu sözel şiddet uygulama davranışının takip ettiği (21) olmuştur. Ayrıca sözel şiddet uygulama davranışı dört ay boyunca gözlenmiştir. Normal gelişim gösteren çocukların az etkileşimde bulunması dikkate alındığında bu davranış sıklıklarının oldukça fazla olduğu görülmektedir. Doğrudan saldırgan davranışlardan fiziksel şiddet uygulama ilk ay görülmemiş olmasına rağmen ikinci aydan itibaren diğer aylarda da gözlemlenmiştir. Ayrıca sözel şiddet uygulamanın (21) fiziksel şiddet uygulamaya kıyasla (9) daha fazla olduğu görülmüştür.

\subsection{Normal Gelişim Gösteren Çocukların, Otizmli Çocuğu Akran Kabulü ve Reddi Açısından Tanımlamalarının Süreç İçerisinde Değişimine Dair Görüşme Bulguları}

Bu bölümde otizmli çocuğun bulunduğu okul öncesi kaynaştırma sınıfinda normal gelişim gösteren çocuklar ile çiz-anlat tekniği kullanılarak yapılan görüşme sonucunda elde edilen veriler sunulmuştur.

Tablo 7'de dönem başı ve sonunda çiz-anlat tekniği kullanılarak yapılan iki görüşmeden elde edilen, normal gelişim gösteren çocukların otizmli çocuğa karşı kabul tanımlarına ilişkin bulgular sunulmuştur. 
Tablo 7. Çocukların Okul Başındaki Otizmli Çocuğa Karşı Kabul Tanımlarına Dair Bulgular

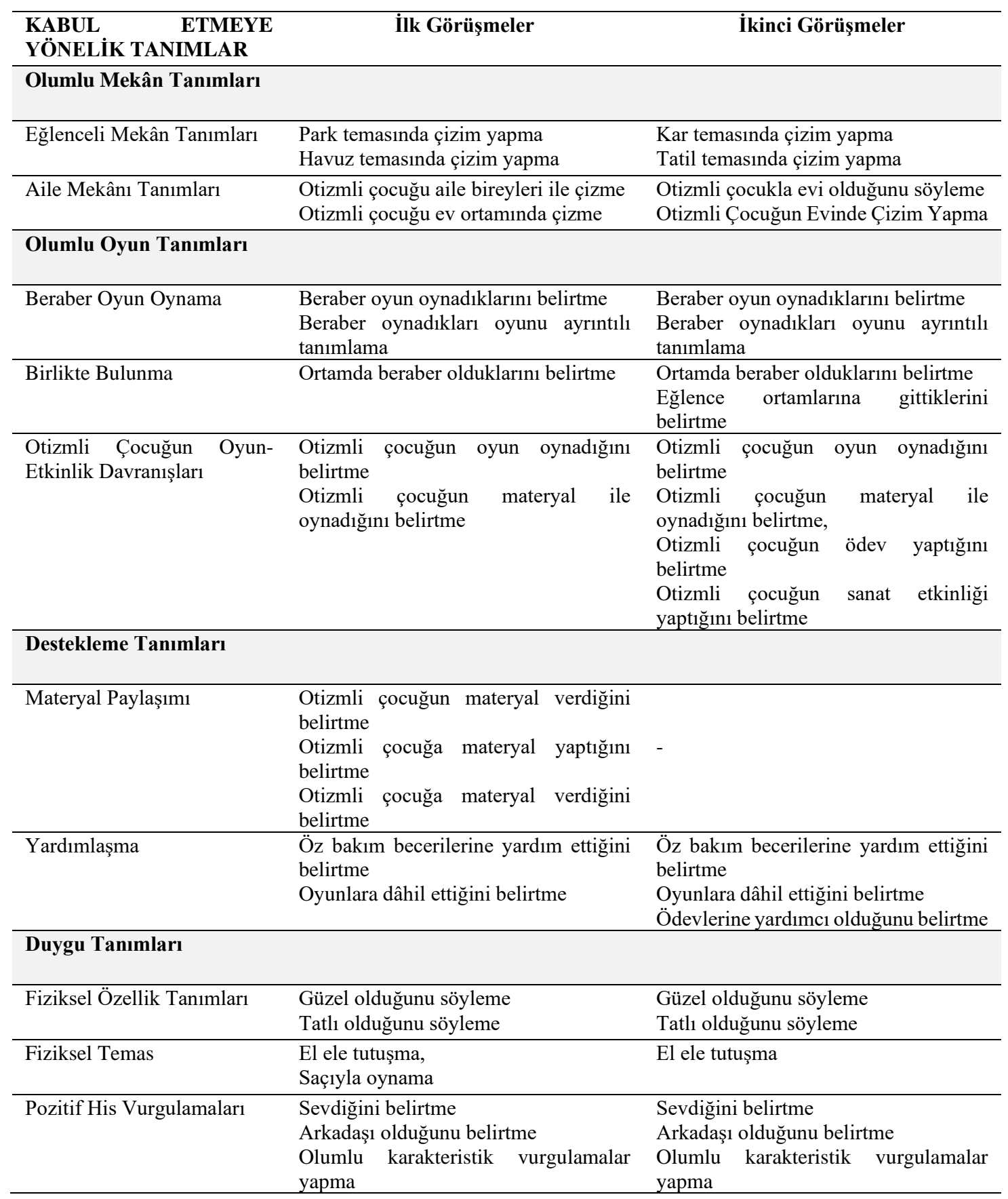

Tablo 7 incelendiğinde; akran kabulüne yönelik tanımlarda süreç içerisinde çok fazla bir değişiklik olmadığı görülmektedir. Otizmli çocuğun oyun-etkinlik davranışları kategorisinde, ilk görüşmelere kıyasla, ikinci yapılan görüşmeler sonucunda otizmli çocuğun ödev yaptı̆̆ını belirtme ve otizmli çocuğun sanat etkinliği yaptığını belirtme alt kategorileri ek olarak söylendiği görülmektedir. Destekleneme tanımlarında, İlk görüşmelerde materyal paylaşımı kategorisi görülürken, ikinci yapılan görüşmelerin bulgularında bu kategoriye dair verilere rastlanılmamıştır. Yardımlaşma kategorisinde; öz bakım becerilerine yardım ettiğini belirtme, oyunlara dâhil ettiğini belirtme ilk görüşme bulguları ile aynı olup; ödevlerine yardımcı olduğunu belirtmenin bu kategoriye yeni eklenen verilerden olduğu görülmektedir. Duygu tanımlarında, olumlu karakteristik vurgulamalar yapma alt kategorisi şımarık olmadığını belirtme, uslu 
olduğunu belirtme gibi kodlardan oluşmaktadır. Duygu tanımlarına dair ilk görüşme örneği aşağıda sunulmuştur;

N21: "Güzel bir klz. İyi kalpli. Mesela diğer kızlarla oyun oynuyor. Legolarla oynuyor ev yapıyor. Ögretmen ona seslendiğinde hemen bakıyor."

N10: "Ö böyle bazen suluğumuzu alıyor. Al diyor. Çantamı getiriyor bazen bana. Her şeyini seviyorum. Çünkü yaramazlık yaptıkça daha çok seviyorum şımarı oluyor."

Tablo 8'de normal gelişim gösteren çocukların otizmli çocuğa karşı ret tanımlarına dair bulgular sunulmuştur.

Tablo 8. Çocukların Okul Başındaki Otizmli Çocuğa Karşı Ret Tanımlarına Dair Bulgular

\begin{tabular}{|c|c|c|}
\hline $\begin{array}{l}\text { REDDETMEYE } \\
\text { YÖNELIK TANIMLAR } \\
\end{array}$ & İlk Görüşmeler & İkinci Görüşmeler \\
\hline $\begin{array}{l}\text { Uyumsuzluğa } \\
\text { Tanımlar }\end{array}$ & & \\
\hline Birlikte Olmama Durumları & $\begin{array}{l}\text { Resimde kendini çizmeme } \\
\text { Görünmez olduğunu söyleme } \\
\text { Bağımsız çizim yapma }\end{array}$ & $\begin{array}{l}\text { Resimde kendini çizmeme } \\
\text { Resimde otizmli çocuğu çizmeme } \\
\text { Bağımsız çizim yapma }\end{array}$ \\
\hline Fikri olmama & ( & $\begin{array}{l}\text { Sevme Nedenini Bilmeme } \\
\text { Otizmli Çocukla İlgili Konuşmama }\end{array}$ \\
\hline Uzaklaştırma Tanımları & $\begin{array}{l}\text { Araçlar ile çocuğu uzaklaştırma } \\
\text { Araçlar ile çocuğa zarar verme } \\
\text { Otizmli çocuğun yanında durmadığını } \\
\text { belirtme }\end{array}$ & $\begin{array}{l}\text { Araçlar ile çocuğu uzaklaştırma } \\
\text { Mekandan kendini uzaklaştırma } \\
\text { Olay örgüsü içerisinde otizmli çocuğu } \\
\text { uzaklaştırma } \\
\text { Otizmli çocuğun yanında durmadığını } \\
\text { belirtme }\end{array}$ \\
\hline Şikayet Tanımları & $\begin{array}{l}\text { Sınıf kurallarına uymadığını belirtme } \\
\text { Ağladığını belirtme } \\
\text { Fiziksel ve sözel şiddet uygulandığını } \\
\text { belirtme }\end{array}$ & $\begin{array}{l}\text { Sınıf kurallarına uymadığını belirtme } \\
\text { Oyuncak ve oyun oynamadığını } \\
\text { belirtme } \\
\text { Sadece bir oyuncakla oynadığını } \\
\text { belirtme, yerinde durmadığını belirtme } \\
\text { Sınıfa zarar verdiğini belirtme } \\
\text { Sınıfla uyumlu etkinlikler } \\
\text { yapmadığını belirtme } \\
\text { Ağladığını belirtme } \\
\text { Fiziksel ve sözel şiddet uygulandığını } \\
\text { belirtme }\end{array}$ \\
\hline $\begin{array}{lc}\text { Olumsuz } & \text { Duygu } \\
\text { Tanımları } & \\
\end{array}$ & & \\
\hline Küçük Olduğunu Düşünme & $\begin{array}{l}\text { Otizmli çocuktan büyük olduğunu } \\
\text { belirtme } \\
\text { Otizmli çocuğun küçük olduğunu } \\
\text { belirtme, } \\
\text { Otizmli çocuğa kendilerinin öğrettiğini } \\
\text { belirtme }\end{array}$ & $\begin{array}{l}\text { Otizmli çocuğun küçük olduğunu } \\
\text { belirtme } \\
\text { Otizmli çocuğa kendilerinin } \\
\text { öğrettiğini belirtme } \\
\text { otizmli çocuğun olayla ilgili deneyimi } \\
\text { olmadığını belirtme }\end{array}$ \\
\hline Yetersizlik Belirtme & $\begin{array}{l}\text { Otizmli çocuğun becerilerinin yetersiz } \\
\text { olduğunu belirtme } \\
\text { Otizmli çocuğun hiçbir şey bilmediğini } \\
\text { belirtme } \\
\text { Otizmli çocuğun } \\
\text { yapamadığını belirtme }\end{array}$ & $\begin{array}{l}\text { Otizmli çocuğun becerilerinin yetersiz } \\
\text { olduğunu belirtme } \\
\text { Otizmli çocuğun hiçbir şey } \\
\text { bilmediğini belirtme } \\
\text { Otizmli çocuğun } \\
\text { yapamadığını belirtme } \\
\begin{array}{l}\text { Otizmli çocuğun öz } \\
\text { yapamadığını belirtme }\end{array}\end{array}$ \\
\hline $\begin{array}{l}\text { Olumsuz } \\
\text { Tanımları } \\
\end{array}$ & & \\
\hline Durağan Eylemler & $\begin{array}{l}\text { Sadece oturduğunu belirtme } \\
\text { Bir şey yapmadığını belirtme }\end{array}$ & $\begin{array}{l}\text { Sadece oturduğunu belirtme, } \\
\text { Bir şey yapmadığını belirtme } \\
\text { Hiç sesini çıkarmadı̆̆ını belirtme } \\
\text { Yavaş hareket ettiğini belirtme }\end{array}$ \\
\hline
\end{tabular}


Tablo 8 incelendiğinde, reddetme tanımlarının çeşitli olduğu görülmektedir. Uyumsuzluğa dair tanımlarda, İlk görüşmelere kıyasla bu tema altında 'fikri olmama' adlı yeni bir kategori oluştuğu görülmektedir.

Uzaklaştırma tanımlarından mekândan kendini uzaklaştırma ve olay örgüsü içerisinde otizmli çocuğu uzaklaştırma alt kategorileri ise ilk yapılan görüşme bulgularında yokken, ikinci yapılan görüşmeler sonucunda görülmüsşür. Ayrıca şikâyet tanımlarının ve olumsuz duygu tanımlarının da ilk yapılan görüşmelere kıyasla çeşitlilik gösterdiği saptanmıştır. Olumsuz duygu tanımlarına dair ilk görüşme alıntıları:

N20: “Ö böyle küçük. Ne yaptığını bilmiyor. Yağmur yağınca araba gelince falan kenara çekilmeyi bilmiyor."

N3: "Ö bazen saçımla oynuyor. Geliyor bazen yanıma. Dediğimi az bir şey anlıyor. Ö onu yerine bırak diyorum bıraklyor bazen bazen de geri alıyor. Hiçbir şey yapmıyor bu kadar. Güzel biri. Seviyorum onu ben"

N11: "Sınıfta oyun oynuyor. Sonra çişi geldiğinde tuvalete kendi gidiyor. Suyunu da kendi içebiliyor. Öyle şeyler yapabiliyor. Küçük biri."

\subsection{Otizmli Çocuğun Kaynaştırma Sınıfındaki Sosyal Konumuna Dair Bulgular}

Otizmli bir çocuğun okul öncesi kaynaştırma sınıfındaki akran ilişkilerini inceleyen bu çalışmada, Ekim ayının başında ve Ocak ayının başında olmak üzere iki kere otizmli çocuğun bulunduğu sınıfta resimli sosyometri tekniği uygulaması yapılmıştır. Normal gelişim gösteren çocuklar n(sayı) şeklinde ifade edilmiş olup otizmli çocuk Ö olarak ifade edilmiştir.

Tablo 9. Okul Öncesi Kaynaştırma Sınıfında Otizmli Çocuğun Sınıf İçerisindeki Sosyal Konumuna Dair Dönem Baş1- Dönem Sonu Test Bilgileri

\begin{tabular}{lll}
\hline Sosyal Statï & Dönem başı & Dönem sonu \\
\hline Popüler & $\mathrm{n} 1, \mathrm{n} 10, \mathrm{n} 15, \mathrm{n} 19$ & $\mathrm{n} 1, \mathrm{n} 8, \mathrm{n} 11, \mathrm{n} 15, \mathrm{n} 18$ \\
\hline Reddedilen & $\mathrm{n} 2, \mathrm{n} 7, \mathrm{n} 21$ & $\mathrm{n} 2, \mathrm{n} 7, \mathrm{n} 9, \mathrm{n} 12, \mathrm{n} 13, \mathrm{n} 17$ \\
\hline İhmal edilen (dışlanan) & $\mathrm{n} 4, \mathrm{n} 14, \mathrm{n} 16$ & $\mathrm{n} 3, \mathrm{n} 13, \mathrm{n} 14$, Ö \\
\hline Tartışmalı & $\mathrm{n} 5$ & $\mathrm{n} 5, \mathrm{n} 21$ \\
\hline Ortalama & $\mathrm{n} 9, \mathrm{n} 11, \mathrm{n} 20, \mathrm{n} 3, \mathrm{n} 17, \mathrm{n} 8$ & $\mathrm{n} 6, \mathrm{n} 19$ \\
\hline Diğer & $\mathrm{n} 6, \mathrm{n} 12, \mathrm{n} 13, \mathrm{n} 22, \mathrm{n} 18$, Ö & $\mathrm{n} 4, \mathrm{n} 20, \mathrm{n} 10, \mathrm{n} 16$ \\
\hline
\end{tabular}

Tablo 9'a bakıldığında otizmli çocuğun (Ö) ilk yapılan sosyometri testinde akranları tarafından hiçbir sosyal grupta yer verilmediği ve bu nedenle "Diğer" kategorisinde ele alındığ görülmektedir. Son yapılan sosyometri testinde ise otizmli çocuğun "İhmal edilen-Dışlanan" grupta yer aldığı belirlenmiştir.

Dönem baş1 sosyometri uygulamasında otizmli çocuğunun ismini söyleyen sadece üç çocuk (n5, n17 ve n21) olduğu saptanmıştır. Bu çocuklardan biri (n5) otizmli çocuğa ilk tercihinde üzgün yüz koymayı tercih ederken; diğer iki çocuk (n17 ve n21) ikinci ve son tercih olarak gülen yüz koymayı tercih etmiştir. Dönem sonu uygulamasında otizmli çocuğun ismini söyleyen sadece iki çocuk (n13 ve yine n21) olduğu belirlenmiştir. İkinci uygulamada otizmli çocuğa üzgün yüz ifadesi koymayı tercih eden hiçbir arkadaşı bulunmazken diğer iki arkadaşı (n13 ve n21) ikinci ve son tercih olarak gülen yüz ifadesi koymayı tercih etmişlerdir.

Genel olarak bakıldığında, dönem sürecinde otizmli çocuk hiçbir arkadaşı tarafından birinci dereceden oyun arkadaşı olarak tercih edilmemiştir. Ayrıca ilk uygulanan sosyometri testinde otizmli çocuğu olumsuz olarak birinci tercihinde belirten bir arkadaşı bulunurken, son yapılan sosyometri testinde olumsuz tercih yapan arkadaşı bulunmamıştır. Otizmli çocuğun arkadaşları tarafından tercih edilme düzeyinin oldukça az olduğu görülmektedir. 


\section{TARTIŞMA, SONUÇ VE ÖNERILER}

$\mathrm{Bu}$ araştırmada, otizm spektrum bozukluğuna sahip çocuğun okul öncesi kaynaştırma sınıfındaki akran ilişkileri akran kabulü, reddi ve zorbalık davranışları temel alınarak incelenmiştir. Bu davranışlar süreçsel olarak değerlendirilmiş ve tartışılmıştır.

Araştırmaya sonuçlarına genel olarak bakıldığında, otizmli çocuğun akran kabulü davranışlarının artışının yanı sıra akran reddi ve zorbalığı davranışları da artış görülmüştür. Normal gelişim gösteren çocukların ise prososyal davranışlarındaki artışa rağmen, otizmli çocuğu görmezden gelme gibi ret davranışları, ilk aydan itibaren sözel şiddet gibi akran zorbalığ davranışları da gösterdikleri saptanmıştır. Ayrıca normal gelişim gösteren çocukların, otizmli çocuğun engelini anlamlandırmadıkları için, onu kendilerinden küçük ve yetersiz gördükleri ortaya çıkmıştır. Son olarak, otizmli çocuğun süreç sonunda dışlanan-ihmal edilen grup kategorisinde bulunduğu saptanmıştır.

Literatürdeki araştırmalarda, okul öncesi dönemde uygulanan kaynaştırma eğitimlerinde, özel gereksinimli çocukların akranlarına karşı pozitif tutumlar sergileyebildikleri belirtilmiştir (Goldstein, English, Shafer ve Kaczmarek, 1997; Sasso ve Rude, 1988). Yapılan bu çalışmada da otizmli çocuğun farklı akran kabulü davranışlarının olduğu, pozitif tutumlar ve davranışlar sergileyebildiği ve akranlarıyla çeşitli etkileşimlerde bulunabildiği saptanmış, fakat etkileşimlerin her zaman kabule yönelik olmadığı da görülmüştür. Araştırmada otizmli çocuk, dönem boyunca yoğun olarak arkadaşlarını izleme davranışı göstermiştir. Metin de (1989), özel gereksinimli çocuklarda en çok görülen davranışın, izleme-bakma davranışı olduğunu saptamıştır. Otizmli çocuğun otizmin doğası nedeniyle yalnız kalmayı tercih ederken, bir diğer yandan sosyal bir ortamda bulunması nedeniyle izleme davranışı sergileyerek pasif de olsa çevresine ilgi gösterdiği düşünülmektedir. Ayrıca otizmli çocuk, okulun başında gözlenmeyen fiziksel temas etme, öneride bulunma ve soru yöneltme gibi akranlarına karşı ilgi davranışlarını da süreç içerisinde göstermeye başlamıştır. Bu da, çocuğun sosyal becerisinin arttığına dair ulaşılan bir yorumdur. Sosyal becerilerin gelişmesi, akran ilişkilerini yakından etkilemekte ve aynı zamanda problem davranışların engellenmesinde kritik öneme sahiptir (Warger ve Rutherford, 1996). Mevcut çalışmada da, otizmli çocuğun sosyal becerilerinin artması, akranlarına karşı ilgisinin artmasına ve olumlu ilişkiler geliştirmesine destek olmuştur. Tüm bunlara karşın; otizmli çocuk, sözlü iletişim başlatma davranışı gösterse de, bu iletişimde devamlılık sağlanamadığı, bunun üzerine kendini sıkma gibi öfke davranışları ve tekrarlayıcı hareketler gösterdiği gözlenmiştir. İlgili alanyazında iletişim becerilerindeki sınırlılikların, sosyal etkileşimlerde düşüşe yol açtığı (Gurnalnick, 1990) ve tekrarlayıcı hareketlerin, çocuğun endişeli olduğu zamanlarda artış gösterdiği bildirilmektedir (Wing, 1996). Ayrıca bu çocukların, sosyal olarak reddedildiklerinin farkında oldukları, bu farkındalığın ise hem davranışsal hem de duygusal sıkıntıya neden olduğu bilinmektedir (Bullock, 1988). Bu çalışmada da iletişim kesikliklerinden dolayı otizmli çocuğun reddedildiğini hissetmesi, kendini sıkma ve tekrarlayıcı davranışlar gibi tutumlar sergilemesine neden olmuş olabilir.

İlgili alanyazında otizmli çocukların, normal gelişim gösteren çocuklara oranla dramatik oyunlarda daha fazla sorunlar yaşadıkları (Charman, Swettenham, Baron Cohen, Cox, Baird ve Drew, 1997) ve hatta genellikle dramatik oyunlar oynamadıkları, oynasa bile düşük kalitede olduğunu (Sherratt, 2002) bildirilmektedir. Mevcut çalışmada, otizmli çocuğun genellikle aynı nesneyle oyun oynamayı tercih ettiği görülmüş, akranlarıyla etkileşim gerektiren diğer oynama davranışlarının (dramatik oyun, manipülatiflerle oyun) ise kısa süreli de olsa gerçekleştiği saptanmıştır.

Otizmli çocuğun akran kabulü davranışlarının yanı sıra, ret ve zorbalık davranışları da görülmüştür. Çocuğun sınıfin tenha köşelerinde vakit geçirme ve arkadaşlarından uzağa oturma davranışları gözlemler boyunca yoğun şekilde görülmüş, otizme bağlı uyumsuz davranışlar, süreçte sık gözlemlenen davranışlar arasında olmuştur. Bu davranışların süreç içerisinde çeşitlenmesi, çocuğun sınıf tarafından reddedilmesinin bir sonucu olarak yorumlanmıştır. Otizme 
bağlı zorbalık davranışlarında kendine zarar verme en çok gözlenen davranış kategorisi olmuştur. Sınıfta fiziksel şiddet dönem başında gözlenmezken, diğer aylarda ortaya çıkmıştır. Sözel şiddet ise dönem başında otizmli çocukta görülmezken, normal gelişim gösteren akranları tarafından ilk aydan itibaren uygulanmıştır. İlgili alanyazında akranları tarafından reddedilen çocukların saldırgan davranışlarının ve öfke krizlerine eğilimlerinin fazla olduğu bildirilmektedir (Campbell, Ferguson, Herzinger, Jackson ve Marino, 2005; Newcomb, Bukowski ve Patee, 1993). Örneğin Newcomb ve arkadaşlarının (1993) 41 çalışmayı dâhil ettikleri meta analiz araştırmasında, akranları tarafından reddedilen ve ihmal edilen çocukların davranış kalıplarının, popüler olanlara kıyasla neredeyse tam tersi olduğu ve bu çocukların diğer sosyometrik kategorilerdeki çocuklara kıyasla daha saldırgan, içine kapanık ve bilişsel, sosyal açıdan daha yetersiz olduğu saptanmıştır. Yapılan bu araştırmada da otizmli çocuğun hem sosyal yetersizlik hissi hem de reddedilme duygusu nedeniyle süreç içerisinde akran reddi ve zorbalığ davranışlarının artış gösterdiği saptanmıştır.

Sınıftaki normal gelişim gösteren çocuklar, otizmli çocuğa karşı oyuna davet etme, sözlü iletişim başlatma, fiziksel temasta bulunma davranışlarını tüm aylarda sergilemiş; diğer aylarda ise otizmli çocuğa oyun kurgulama, otizmli çocuğu yanına çağırma, otizmli çocuğa öneride bulunma, otizmli çocuğa soru yöneltme, otizmli çocuğu diğer arkadaşlarına yönlendirme, otizmli çocuğun oyununa dâhil olma davranışları oluşmuştur. Kısaca kabule yönelik davranışlarda artış gözlenmiştir. Farklı akranlarla etkileşim kurabilen çocukların, önyargılarının azaldığı ve olumlu bir gelişim yörüngesine girdikleri bilinmektedir (Elenbaas, 2019). Ayrıca bu sayede özgüven duygusunda artış, okuldaki sorunların azalması gibi sonuçlar da elde edilebilir (Graham, Munnisksma ve Juvoven, 2014; Özdemir ve Özdemir, 2020). Barrafato (1998), yaptığı çalışmada hem özel gereksinimli çocukların hem de normal gelişim gösteren akranlarının, kaynaştırma programı sayesinde sosyal alanlarda gelişmeler edindikleri saptamıştır. Mevcut çalışmada da, kabule yönelik bulgular göz önüne alındığında, normal gelişim gösteren çocuklarda süreç içerisinde prososyal davranışlar geliştiği açıkça görülmektedir.

Normal gelişim gösteren çocukların akran reddi davranışlarında tepkisizlik ve uzaklaşma davranışları dikkat çekmiş, küçümseme, garip bulma gibi davranışlar ise ilk aydan sonra oluşmaya başlamıştır. Daha önce yapılan çalışmalar incelendiğinde; özel eğitime ihtiyacı olan çocukların sınıftaki diğer çocuklar tarafından genellikle görmezden gelme davranışına maruz kaldıkları görülmektedir (Çulhaoğlu İmrak, 2009; Kabasakal vd., 2008; Karadağ, Demirtaş ve Girli, 2014). Örneğin Karadağ ve arkadaşları (2014), anaokulundaki özel gereksinimli çocuklarla yaptıkları araştırma sonucunda, bu çocukların akranları tarafından yüksek düzeyde görmezden gelindiğini saptamıştır. Bu çalışmada da yoğun şekilde tepki vermeme, yanıt vermeme ve uzaklaşma davranışları görülmüş, otizmli çocuğun akranları tarafından görmezden gelindiği saptanmıştır. Literatürde vurgulandığı gibi kaynaştırma programının verimli geçmemesi sonucu, ilk aydan sonra sınıftaki olumsuz davranışlarda artış görülmüştür.

Normal gelişim gösteren çocukların akran zorbalığında en çok görülen davranışlar alay etme ve sözel şiddet olmuştur. Sözel şiddet, dönem başı da dâhil olmak üzere yoğun şekilde görülmüş, fiziksel şiddet aynı otizmli çocuk gibi ilk aydan sonra görülmeye başlamıştır. Pivik, McComas ve Laflamme (2002), özel gereksinimli çocukların sınıftaki akranlarınca zorbalığa uğradıklarını belirtmiştir. Başka bir çalışmada da normal gelişim gösteren çocukların özel gereksinimli çocuğa karşı sosyal ve sözel zorbalığın fiziksel zorbalığa kıyasla daha fazla sergiledikleri gözlemlenmiştir (Son, 2011). Mevcut çalışmada da sözel zorbalı̆̆ın fiziksel zorbalıktan daha fazla olduğu görülmektedir. Normal gelişim gösteren çocukların daha önce yaşantılarının özel gereksinimli bireylerin olmaması, bu çocuklar arasında yaşanan çatışma ve uyumsuzlukların temel nedenleri olarak vurgulanmaktadır (Walker, Berthelsen, 2007). Bu uyumsuzluklar ve anlamlandırma sorunları nedeniyle bu çocuklar arasındaki sosyal etkileşimlerin daha az ve düşük düzeyde gerçekleştiği belirtilmektedir. (Gimenez, 2001).

Normal gelişim gösteren çocukların otizmli çocuğu kabule yönelik tanımları ve söylemleri süreç içerisinde fazla değişikliğe uğramamış, akran reddine yönelik tanımları ve söylemlerinde 
ise büyük farklar gözlenmiştir. Diamond ve Hestenes (1996) yaptıkları çalışma sonucunda, çocukların özel gereksinimli çocuğa karşı olumlu söylemlerine karşın, davranışların bu tanımlarla tutarlı olmadığını belirtmişlerdir. Mevcut çalışmada da normal gelişim gösteren çocukların otizmli çocukla ilgili söylemleri ile bu çocuğa karşı davranışları arasında tutarsızlıklar olduğu gözlenmiştir. Çocukların bu dengeli olmayan söylem ve davranışlarının arkasında kaynaştırma programının verimli uygulanamaması, çocukların otizmli çocuğun özel durumu hakkında bilgi sahibi olmaması, öğretmeni model almaları, farklı sosyal konumdaki çocukların otizmli çocuğa karşı davranış ve tutumları gibi çeşitli etkenler olabilir.

Normal gelişim gösteren çocuklarla görüşmelerde otizmli arkadaşlarını küçük görme ve yetersiz görme tanımları ve söylemleri dikkat çekmiştir, çocuklar otizmli çocuğun kendilerinden küçük yaşta olduğunu düşündükleri belirlenmiştir. Bunun en temel nedeni, normal gelişim gösteren çocuklar otizmli çocuğun özel gereksiniminden haberdar olmamalarıdır. Bu nedenle onun sınırlı becerilere sahip olmasını, yaşının küçük olduğu düșüncesi ile ilișkilendirmișlerdir. İlgili alan yazın incelendiğinde, okul öncesi çocuklarının özel gereksinimli çocukların kendilerinden farklı göründüklerine ve davranışlarının bir kısmını anlamlandırabildiklerini gösteren çalışmalar bulunmaktadır (Diamond, Furgy ve Blass, 1993; Diamond ve Hestenes, 1996). Örneğin Diamond ve Hestenes (1996), okul öncesi çocuklarıyla yaptıkları çalışmada, normal gelişim gösteren çocukların fiziksel engelli çocuklara karşı duyarlı oldukları, fakat diğer engel türlerini anlamlandırmakta zorlandıklarını saptamışlardır. Bu çalışmada da çocukların farklılıkları algıladığı, fakat tam bir tanımlama yapamadıkları, genelde kendilerinden küçük olduğunu düşündükleri ifade ettikleri görülmüştür. Yapılan daha önceki çalışmaların sonuçlarıyla paralel olarak, mevcut çalışmada normal gelişim gösteren çocuklar da, otizmli çocuğun bazı becerilerden yoksun oldukları ve bir şeyleri yapma konusunda kendilerine muhtaç olduğunu düşünmelerine neden olmaktadır (Swadener, 1989). Türkiye'de yapılan çalışmalar incelendiğinde, genel olarak özel eğitime ihtiyacı olan çocuklara karşı olumlu tutum, davranış ve alg1 olmasına rağmen; bu bireylere acıma, tercih etmeme gibi olumsuz tutumlar da bulundukları bilinmektedir (Özürlüler İdaresi Başkanlığı, 2011).

Son olarak, otizmli çocuğun, okulun başında arkadaşlar arasındaki sosyal gruplardan hiçbirine girmedikleri ve diğer kategorisinde yer aldığı süreç sonunda ise dışlanan-ihmal edilen çocuk kategorisinde yer aldığı saptanmıştır. Ayrıca otizmli çocuğun hiçbir arkadaşı tarafindan birinci derecede tercih edilmediği görülmüş̧ür. Kaynaştırma sınıfındaki özel gereksinimli çocukların, sınıf ortamında tercih edilme düzeyinin az olduğu ve bunun sosyal becerilerindeki yetersizliklerden kaynaklandığı düşünülmektedir (Baydık ve Bakkaloğlu, 2009; Sucuoğlu, Özokçu, 2005). Yapılan bu çalışmada da otizmli çocuğun tercih edilme düzeyinin oldukça düşük olduğu belirlenmiştir.

$\mathrm{Bu}$ çalışma, otizmli bir çocuğun kaynaştırma sınıfındaki akran ilişkilerine dair önemli bulgular sunmakla beraber, özel bir durumu temsil etmektedir. Araștırmalarda, okul öncesi dönemde kaynaştırma sınıflarındaki otizmli çocukların akran ilişkilerinin incelenmesi, programdan verim alma açısından kritik önem taşımaktadır. Çocukların birbirleriyle olumsuz etkileşimleri, kısır bir döngüye dönüşmektedir ve her iki tarafın da kaynaştırmanın fırsatlarından mahrum kalmasına neden olmaktadır. $\mathrm{Bu}$ nedenle kaynaştırma sınıfları düzenli olarak denetlenmeli, öğretmenlerin çocuklara daha iyi rehberlik edebilmesi için kaynaştırma eğitimi, akran ilişkileri farkındalık-geliştirme yöntemleri, özel eğitim gibi eğitim destekleri sağlanmalıdır. Özellikle akran etkileşimine arttırmaya yönelik stratejiler (akran eşleştirme, işbirlikli öğrenme vb.) ile ilgili müdahaleler geliştirilebilir (Hanish vd., 2021) ve öğretmenlere bu stratejilerle ilgili eğitim verilebilir. Ek olarak, bu çalışmadaki normal gelişim gösteren çocuklara, otizmli çocuğun özel durumu ile ilgili bilgilendirme yapılmaması nedeniyle, otizmli çocuğa farklı tanımlar geliştirmişlerdir. Sonraki araştırmalarda, kaynaştırma ve engel durumu ile ilgili bilgilendirme yapılmış olan sınıflarda çalışılabilir. Ayrıca otizmli çocuklar dışında diğer engel gruplarının da bulunduğu okul öncesi kaynaştırma sınıflarındaki akran ilişkileri incelenebilir. 


\section{KAYNAKÇA}

Abbak Kaçar, B. (2019). Okul öncesi kaynaştırma sınıfinda akran ilişkilerinin geliştirilmesine yönelik durum çalışması: Akran aracılı eğitim (Doktora tezi). Çukurova Üniversitesi. Adana.

Aksoy, F. (2018). Severity levels of autism, social interaction behaviours and school adjustment of pre-school children with autism spectrum disorder. International Journal of Early Childhood Special Education, 10(1), 110.

Arslan, E. (2010). Kaynaştırma uygulamalarına katılan engelli öğrencilerin sosyal kabul düzeylerinin belirlenmesine yönelik ölçek geliştirme çalışması (Yüksek Lisans Tezi). Mehmet Akif Ersoy Üniversitesi, Sosyal Bilimler Enstitüsü, Burdur.

Attwood, T. (2000). Strategies for improving the social integration of children with Asperger syndrome. Autism, 4(1), 85-100.

Balli, (2020). Okul öncesi özel gereksinimli çocuklarda sosyal etkileşim becerileri ile davranış sorunları arasındaki ilişsk (Yüksek Lisans Tezi). Maltepe Üniversitesi, İstanbul.

Barrafato, A. (1998). Inclusion at the early childhood level: Supports contributing to its success (Doctoral dissertation). Concordia University.

Bauminger, N. \& Kasari, C. (2000). Loneliness and friendship in high-functioning children with autism. Child development, 71(2), 447-456.

Baydık, B. ve Bakkaloğlu, H. (2009). Alt sosyoekonomik düzeydeki özel gereksinimli olan ve olmayan ilköğretim öğrencilerinin sosyometrik statülerini yordayan değişkenler. Kuram ve Uygulamada Eğitim Bilimleri, 9(2), 401-447.

Baysal-Metin, N. (1989). Okul öncesi çağındaki down sendromlu ve normal gelişim gösteren çocukların entegrasyonunda sosyal iletişsim davranışlarının incelenmesi(Yayınlanmamış Doktora Tezi). Hacettepe Üniversitesi, Ankara.

Beyazkürk, D., Anliak, Ş. ve Dinçer, Ç. (2007). Çocuklukta akran ilişkileri ve arkadaşlık. Eurasian Journal of Educational Research (EJER), 26, 13-26.

Buhs, E. S. \& Ladd, G. W. (2001). Peer rejection as antecedent of young children's school adjustment: An examination of mediating processes. Developmental Psychology, 37(4), 550 .

Bullock, C. C. (1988). Interpretive lines of action of mentally retarded children in mainstreamed play settings. Studies in Symbolic Interaction:A Research Annual, 9, 145-174.

Campbell, J. M., Ferguson, J. E., Herzinger, C. V., Jackson, J. N. \& Marino, C. (2005). Peers' attitudes toward autism differ across sociometric groups: An exploratory investigation. Journal of Developmental and Physical Disabilities, 17(3), 281-298.

Chamberlain, B., Kasari, C. \& Rotheram Fuller, E. (2007). Involvement or isolation? The social networks of children with autism in regular classrooms. Journal of Autism and Developmental Disorders, 37(2), 230-242.

Charman, T., Swettenham, J., Baron Cohen, S., Cox, A., Baird, G. \& Drew, A. (1997). Infants with autism: An investigation of empathy, pretend play, joint attention, and imitation. Developmental Psychology, 33(5), 781.

Crick, N. R. (1995). Relational aggression: The role of intent attributions, feelings of distress, and provocation type. Development and Psychopathology, 7(2), 313-322.

Çulhaoğlu İmrak, H. ve Sığırtmaç, A. (2010). Kaynaştırma uygulanan okulöncesi sınıflarında akran ilişkilerinin incelenmesi. International Journal of Early Childhood, 3(1), 38-65. 
Dean, M., Adams, G. F. \& Kasari, C. (2013). How narrative difficulties build peer rejection: A discourse analysis of a girl with autism and her female peers. Discourse Studies, 15(2), 147-166.

Diamond, K. E. \& Hestenes, L. L. (1996). Preschool children's conceptions of disabilities: The salience of disability in children's ideas about others. Topics in Early Childhood Special Education, 16(4), 458-475.

Diamond, K. E. \& Hong, S. Y. (2010). Young children's decisions to include peers with physical disabilities in play. Journal of Early Intervention, 32(3), 163-177.

Diamond, K. \& Tu, H. (2009). Relations between classroom context, physical disability and preschool children's inclusion decisions. Journal of Applied Developmental Psychology, 30(2), 75-81.

Diamond, K., Furgy, W. L. \& Blass, S. (1993). Attitudes of preschool children toward their peers with disabilities: A year-long investigation in integrated classrooms. The Journal of Genetic Psychology, 154(2), 215-221.

Duman, G. ve Koçak, N. (2013). Anaokulu kaynaştırma sınıfında yer alan özel gereksinimli bir çocuğun sosyal oyun ve sosyal iletişim özellikleri. Cumhuriyet International Journal of Education, 2(3), 99-108.

Elenbaas, L. (2019). Interwealth contact and young children's concern for equity. Child Development, 90, 108-116. https://doi.org/10.1111/cdev.13157

Erdoğan, F. K. (2019). Akran etkileşiminin otizm spektrum bozukluğu olan bir bireyin dil ve oyun gelişimine etkisinin incelenmesi. (Yayımlanmamış Yüksek Lisans Tezi). Necmettin Erbakan Üniversitesi Sağlık Bilimleri Enstitüsü. Konya.

Erol, İ. (2012). Engellerin ötesinde: kaynaştırma ögrencilerinin okul ve sosyal yaşamlarının etnografik analizi. (Yayınlanmamış Yüksek Lisans Tezi). Çanakkale Onsekiz Mart Üniversitesi Eğitim Bilimleri Enstitüsü, Çanakkale.

Erten, H. (2012). Okul öncesi eğitime devam eden 5-6 yaş çocuklarının sosyal beceri, akran ilişsileri ve okula uyum düzeyleri arasındaki ilişkilerin izlenmesi (Yayınlanmamış Doktora Tezi). Pamukkale Üniversitesi Sosyal Bilimler Enstitüsü, Denizli.

Ferreira, M., Aguiar, C., Correia, N., Fialho, M. \& Pimentel, J. S. (2019). Friendships and social acceptance of Portuguese children with disabilities: The role of classroom quality, individual skills, and dosage. Topics in Early Childhood Special Education, 39(3), 183195.

Ganz, J. B. \& Flores, M. M. (2008). Effects of the use of visual strategies in play groups for children with autism spectrum disorders and their peers. Journal of Autism and Developmental Disorders, 38(5), 926-940.

Gimenez, M. E. (2001). Marxism, and class, gender, and race: Rethinking the trilogy. Race, Gender \& Class, 8(2). 23-33.

Girli, A. ve Atasoy, S. (2010). Otizm tanılı kaynaştırma öğrencilerine uygulanan bilişsel süreç yaklaşımına dayalı sosyal beceri programının etkililiğinin incelenmesi. Illköğretim Online, 9(3), 990-1006.

Girli, A. ve Atasoy, S. (2012). Kaynaştırmaya yerleştirilen zihin yetersizliği veya otistik özellikleri olan öğrencilerin okul yaşantıları ve akranlarıyla ilişkilerine ilişkin görüşleri. Dokuz Eylül Üniversitesi Buca Eğitim Fakültesi Dergisi, (32), 16-30. 
Goldstein, H. ve Cisar, C. L. (1992). Promoting interaction during sociodramatic play: Teaching scripts to typical preschoolers and classmates with disabilities. Journal of Applied Behavior Analysis, 25(2), 265-280.

Goldstein, H., English, K., Shafer, K. \& Kaczmarek, L. (1997). Interaction among preschoolers with and without disabilities: Effects of across-the-day peer intervention. Journal of Speech, Language, and Hearing Research, 40(1), 33-48.

Guralnick, M. J. (1990). Social competence and early intervention. Journal of Early Intervention, 14(1), 3-14.

Gülay, H. (2010). Okul öncesi dönemde akran ilişkileri. Pegem Akademi Yayıncılık, Ankara.

Güven, D. ve Diken, I. H. (2014). Otizm spektrum bozukluğu olan okul öncesi çocuklara yönelik sosyal beceri öğretim müdahaleleri. Ankara Üniversitesi Eğitim Bilimleri Fakültesi Özel Ĕ̈itim Dergisi, 15(1), 19-38.

Güzel Özmen, R. (2003). Kaynaştırma ortamlarında ögrretimsel düzenlemeler. Özel eğitime giriş (51-83). Ankara: Gündüz Education and Publishing.

Graham, S., Munniksma, A. \& Juvonen, J. (2014). Psychosocial benefits of cross-ethnic friendships in urban middle schools. Child Development, 85, 469-483.

Hanish, L. D., Martin, C. L., Cook R., DeLay, D., Lecheile, B., Fabes, R. A., Goble, P. \& Bryce, C. (2021). Building integrated peer relationships in preschool classrooms: The potential of buddies, Journal of Applied Developmental Psychology, 73. https://doi.org/10.1016/j.appdev.2021.101257.

Harper, L. V. \& McCluskey, K. S. (2002). Caregiver and peer responses to children with language and motor disabilities in inclusive preschool programs. Early Childhood Research Quarterly, 17(2), 148-166.

Hartup, W. W. (1970). Peer interaction and social organization. Carmichael's Manual of Child Psychology, 2, 361-456.

İmrak, H. (2009). Okulöncesi dönemde kaynaştırma eğitimine ilişkin öğretmen ve ebeveyn tutumları ile kaynaştırma eğitimi uygulanan sinıflarda akran ilişsilerinin incelenmesi. (Yayınlanmamış Yüksek Lisans Tezi). Çukurova Üniversitesi Sosyal Bilimler Enstitüsü, Adana.

Jamero, J. L. F. (2019). Social constructivism and play of children with autism for inclusive early childhood. International Journal of Early Childhood Special Education, 11(2), 154-167.

Kabasakal, Z., Girli, A., Okun, B., Çelik, N. ve Vardarlı, G. (2008). Kaynaştırma öğrencileri, akran ilişkileri ve akran istismarı. Dokuz Eylül Üniversitesi Buca Eğitim Fakültesi Dergisi, 23(1), 169-176.

Karadağ, F., Yıldız Demirtaş, V. \& Girli, A. (2014). Okul öncesi dönemde akranların sınıflarındaki özel gereksinimli öğrenciyi tercih etme durumları. Mehmet Akif Ersoy Üniversitesi Ë̆itim Fakültesi Dergisi, 1(31), 191-215.

Kaya, A. (2005). Farklı sosyometrik statülerdeki ilköğretim II. kademe öğrencilerinin benlik kavramı ve yalnızlık düzeyleri. Türk Psikolojik Danışma ve Rehberlik Dergisi, 3(23), 7-19.

Koagel, L. K. , Koagel, R. L., Frea W. D. \& Freeden, R. M. (2001) Identifying early intervention targets for children with autism in inclusive school settings. Behavior Modification 25(5), 745-761.

Küçüker, S., Erdoğan, N. I. \& Çürük, Ç. (2014). Peer acceptance of children with disabilities in inclusive kindergarten classrooms. Pamukkale Üniversitesi Ĕgitim Fakültesi Dergisi, 36, 163-177. 
Laushey, K. M. \& Heflin, L. J. (2000). Enhancing social skills of kindergarten children with autism through the training of multiple peers as tutors. Journal of Autism and Developmental Disorders, 30(3), 183-193.

Mason, Jennifer (1996). Qualitative Researching. London: Sage.

Maxwell, J. A. (2008). Designing a qualitative study. The SAGE Handbook of Applied Social Research Methods, 2, 214-253.

Menteş, H. S. ve Arnas, Y. A. (2019). Okul öncesi kurumuna kaynaştırılan otizm spektrum bozukluğuna sahip bir çocuğun akran ilişkilerinin incelenmesi, The Quest for the Relationship between Active Learning and Students' Potential içinde (s. 146-156). International Symposiun On Active Learning Kongre'sinde sunulan bildiri, Adana, Türkiye.

Metin, N., Şenol, B. ve Yumuş, M. (2015). Investigation of sociometric status of autistic children included in pre-school education classes. Hacettepe University Faculty of Health Sciences Journal, 3rd National Congress of Child Development and Education Congress Book içinde (s. 483-490), Ankara.

Huberman, A. M. \& Miles, M. B. (1994). Data management and analysis methods. Sage.

Morgan, David L. (1988), Focus Groups as Qualitative Research, Beverly Hills, CA: Sage.

Newcomb, A. F., Bukowski, W. M., \& Pattee, L. (1993). Children's peer relations: A metaanalytic review of popular, rejected, neglected, controversial, and average sociometric status. Psychological Bulletin, 113(1), 99.

Odom, L S., Deciyan, M., \& Lenkins. R.J. (1984). Integrating handicapped and nonhandicap-ped preschoolers: Developmental impact on nonhan-dicapped children. Exceptional Children, $51(1), 41-48$.

Odom, S. L., Zercher, C., Li, S., Marquart, J. M., Sandall, S. ve Brown, W. H. (2006). Social acceptance and rejection of preschool children with disabilities: A mixed-method analysis. Journal of Educational Psychology, 98(4), 807.

Ogelman, H. G. ve Erten, H. (2013). 5-6 yaş çocuklarinin akran ilişkileri ve sosyal konumlarinin okula uyum düzeyleri üzerindeki yordayici etkisi (boylamsal çalışma). Selçuk Üniversitesi Sosyal Bilimler Enstitüsü Dergisi, (30), 453-163.

Ozdemir, S. B., \& Ozdemir, M. (2020). The role of perceived inter-ethnic classroom climate in adolescents' engagement in ethnic victimization: For whom does it work? Journal of Youth and Adolescence, 49, 1328-1340. https://doi.org/10.1007/s10964-020-01228-8

Özmen, D. (2013). 5-6 yaş grubu çocukların akran ilişkilerinin sosyal problem çözme becerisi açısından incelenmesi (Doktora Tezi). Selçuk Üniversitesi Sosyal Bilimler Enstitüsü, Konya.

Payne, A. A. (2010). Successful reintegration into a special school. Good Autism Pratice, 11(1) $16-22$.

Pivik, J., McComas, J. ve Laflamme, M. (2002). Barriers and facilitators to inclusive education. Exceptional Children, 69(1), 97-107.

Pridmore, P. \& Bendelow, G. (1995). Health images: exploring children's beliefs using the draw and write technique. Health Education Journal, 54(4), 473-488.

Punch, K. F. \& Oancea, A. (2014). Introduction to research methods in education. Sage.

Reichow, B. \& Volkmar, F. R. (2010). Social skills interventions for individuals with autism: Evaluation for evidence-based practices within a best evidence synthesis framework. Journal of Autism and Developmental Disorders, 40(2), 149-166. 
Sali, G. (2014). Okul öncesi dönem çocuklarında akran ilişkilerinin ve akran şiddetine maruz kalmanın çeşitli değişkenler açısından incelenmesi. Çukurova University Faculty of Education Journal, 43(2), 195.

Sasso, G. ve Rude, H. A. (1988). The social effects of integration on nonhandicapped children. Education and Training in Mental Retardation, 3(1), 18-23.

Seidman, I. E. (1991). Interview as qualitative research. a guide for researchers in education and the social studies. New York, NY: Teachers College.

Sewell, K. (2011). Researching sensitive issues: a critical appraisal of 'draw-and-write' as a data collection technique in eliciting children's perceptions. International Journal of Research \& Method in Education, 34(2), 175-191.

Sherratt, D. (2002). Developing pretend play in children with autism: A case study. Autism, 6(2), 169-179.

Sigman, M., Ruskin, E., Arbelle, S., Corona, R., Dissanayake, C., Espinosa, M., ... \& Robinson, B. F. (1999). Continuity and change in the social competence of children with autism, Down syndrome, and developmental delays. Monographs of the Society for Research in Child Development, 139.

Son, E. (2011). Peer victimization of children with disabilities: Examining prevalence and early risk and protective factors among a national sample of children receiving special education services. Rutgers The State University of New Jersey-New Brunswick.

Sucuoğlu, B. ve Özokçu, O. (2005). Kaynaştırma öğrencilerinin sosyal becerilerinin değerlendirilmesi. Ankara Üniversitesi Eğitim Bilimleri Fakültesi Özel Eğitim Dergisi, 6(01), 41-65.

Swadener, E.B. (1989). Race, gender, and exceptionality: Peer interactions in two child care centers. Educational Policy, 3(4), 371-387.

Şen, B. ve Özbey, Ş. (2017). Okul öncesi dönem çocuklarının duygusal zekâ düzeyleri ile akran ilişkileri arasındaki ilişkinin incelenmesi. Education Sciences, 12(1), 40-57.

T1kıroğlu, Ç. (2019). Tipik gelişen çocukların oyun etkinlikleri sirasında akran aracılı uygulamaları kullanmalarının tipik gelişen ve otizm spektrum bozukluğuna sahip çocukların sosyal etkileşim davranışları üzerindeki etkileri (Yayımlanmamış Doktora Tezi). Anadolu Üniversitesi Eğitim Bilimleri Enstitüsü, Eskişehir.

Warger, C. L. \& Rutherford, R. (1996). Social skills instruction: A collaborative approach. Washington: Foundation for Exceptional Innovations.

White, S. W., Koenig, K. ve Scahill, L. (2010). Group social skills instruction for adolescents with high-functioning autism spectrum disorders. Focus on Autism and Other Developmental Disabilities, 25(4), 209-219

Wing, L. (1996). Otizm El Rehberi (Çev. Kunt, S.). Türkiye Otizm Erken Tanı ve Eğitim Vakfi, Doğan Kitap Yayınevi.

Wolfberg, P. J., Zercher, C., Lieber, J., Capell, K., Matias, S., Hanson, M. ve Odom, S. L. (1999). "Can I play with you?" Peer culture in inclusive preschool programs. Journal of the Association for Persons with Severe Handicaps, 24(2), 69-84.

Wood, J. J., Cowan, P. A. \& Baker, B. L. (2002). Behavior problems and peer rejection in preschool boys and girls. The Journal of Genetic Psychology, 163(1), 72-88.

Yoleri, S. (2015). Preschool children's school adjustment: indicators of behaviour problems, gender, and peer victimisation. Education, 43(6), 630 - 640. 


\section{EXTENDED ABSTRACT}

\section{Introduction}

Considering that the rate of participation of children with autism in inclusive education is increasing, further research is required on the type and quality of peer relationships in these classrooms. The aim of this study is to examine the relationships of a child with autism with her peers in a preschool inclusive class. Peer relationships were examined in three dimensions; peer acceptance, peer rejection and bullying and answers were sought for the following questions.

1. How do peer relationships in an inclusive preschool classroom with a child with autism change during the study period in terms of peer acceptance, rejection, and bullying behaviors?

2. How do the definitions pertaining to the child with autism by normally developing children in the inclusive classroom change in terms of peer rejection and acceptance during the study period?

3. How does the social status of the child with autism in the inclusive classroom change during the study period?

\section{Method}

This study, which aims to examine the peer relationships of a child with autism in a preschool inclusive class, was conducted as a descriptive case study because of the complex and variable structure of behaviors, the natural environment of inclusion education, the meaning and description of this context, and the fact that children with autism represent a special phenomenon (Maxwell , 2008). Participants consist of a child born in 2014 with autism and 21 children with normal development, 10 girls and 11 boys between the ages of 60-72 months in an inclusive classroom in a kindergarten in Adana province affiliated to Ministry of National Education in the 2019-2020 academic year. The classroom in which the study was conducted was chosen by means of easily accessible situation sampling, one of the purposeful sampling methods, due to the scarcity of children with autism in preschool inclusive classes and being on an economically viable route. Some of the normally developing children were in the same group with the child with autism in the previous academic year. The children were not briefed about the child with autism, as her family requested that her condition to be kept confidential. The child with autism is a girl. She was diagnosed with atypical autism at the age of 4 and has been attending both the special education center and kindergarten as a full-time inclusion student since that age. The participant with autism has difficulty in expressive language skills, usually communicates using single or two-word expressions. Her receptive language skills are at a high level. Observation and interview (draw-and-tell and sociometry) were used as data collection tools. Semi-structured observation was preferred in the study. Observations were made three times in September, October, November and December 2019. Each observation was made during play activities where the natural interactions of the children were most intense and lasted approximately 45 minutes. Focusing on their behavior towards the child with autism and their peers, during the observation, the data of all peers who communicated and interacted with the child with autism were recorded. In the draw-and-tell technique, which was applied twice at the beginning and end of the term, firstly, each child in the class was asked to draw a picture of the child with autism and herself/himself. After the children explained the pictures they drew, a total of 4 questions were asked about their relationship with the child with autism. The sociometry technique was used to obtain a different perspective on peer relationships, to examine group dynamics and the social status of the child with autism. In the study, firstly, each child was shown a material with photographs of the children, and they were asked respectively to place a smiling face card on the photos of the 3 friends they preferred to play with, and then to place sad face card on the photos of the 3 friends they did not prefer to play games with. In addition, in this sociometry application, the children who placed a card on the autistic child's photo were asked, "Why do you like to play with her?, Can you explain?, What are you doing with your friend in class?" or "Why don't you 
like to play with her?, What is your friend doing in class?". The data of the study consisted of 480 minutes of video recordings, observation notes, 43 pictures drawn by children with normal development, photographs of the physical environment of the classroom, notes taken during sociometry and 71 pages of text obtained from interviews and transferred to the computer environment. Regularly during the data collection process, the data obtained were simultaneously analyzed by content analysis method.

\section{Results}

The study reveals in general, that peer rejection and bullying behaviors as well as the increase in peer acceptance behaviors towards the child with autism were observed to be extensive. In conjunction with the increase in the prosocial behaviors of the children with normal development, it was found that they also displayed rejection behaviors such as ignoring the autistic child and peer bullying behaviors such as verbal violence starting from the first month. In addition, it has been revealed that normally developing children perceive the child with autism to be inferior and incompetent because they cannot comprehend her disability. Finally, it was determined that the child with autism was in the excluded-neglected group category at the end of the study period.

\section{Conclusion and Discussion}

Although this study provides important findings about the peer relationships of a child with autism in the inclusive classroom, it presents a specific case. Examining the peer relationships of children with autism in inclusive preschool classrooms through research is critical for increasing the efficiency of the program. Children's negative interactions with each other develop into a vicious cycle, leaving both sides deprived of opportunities for inclusion. In addition, due to the fact that normally developing children in this study were not informed about the special condition of the child with autism, they developed different definitions pertaining to the child with autism. Future research can be conducted in classrooms where information about inclusion and disability has been provided. In addition, peer relationships in preschool inclusive classes, where there are other disability groups other than children with autism, can be examined. 